\title{
Well-Dispersed Nanoscale Zero-Valent Iron Supported in Macroporous Silica Foams: Synthesis, Characterization, and Performance in Cr(VI) Removal
}

\author{
Chaoxia Zhao, Jie Yang, Yihan Wang, and Bo Jiang \\ College of Chemistry, Sichuan University, Chengdu 610064, China \\ Correspondence should be addressed to Jie Yang; j.yang@scu.edu.cn
}

Received 8 May 2017; Revised 4 July 2017; Accepted 30 July 2017; Published 10 September 2017

Academic Editor: Eric Guibal

Copyright (C) 2017 Chaoxia Zhao et al. This is an open access article distributed under the Creative Commons Attribution License, which permits unrestricted use, distribution, and reproduction in any medium, provided the original work is properly cited.

\begin{abstract}
Well-dispersed nanoscale zero-valent iron (NZVI) supported inside the pores of macroporous silica foams (MOSF) composites (Mx-NZVI) has been prepared as the $\mathrm{Cr}(\mathrm{VI})$ adsorbent by simply impregnating the MOSF matrix with ferric chloride, followed by the chemical reduction with $\mathrm{NaHB}_{4}$ in aqueous solution at ambient atmosphere. Through the support of MOSF, the reactivity and stability of NZVI are greatly improved. Transmission electron microscopy (TEM) results show that NZVI particles are spatially well-dispersed with a typical core-shell structure and supported inside MOSF matrix. The $\mathrm{N}_{2}$ adsorption-desorption isotherms demonstrate that the Mx-NZVI composites can maintain the macroporous structure of MOSF and exhibit a considerable high surface area $\left(503 \mathrm{~m}^{2} \cdot \mathrm{g}^{-1}\right)$. X-ray photoelectron spectroscopy (XPS) and powder X-ray diffraction (XRD) measurements confirm the core-shell structure of iron nanoparticles composed of a metallic $\mathrm{Fe}^{0}$ core and an $\mathrm{Fe}(\mathrm{II}) / \mathrm{Fe}(\mathrm{III})$ species shell. Batch experiments reveal that the removal efficiency of $\mathrm{Cr}(\mathrm{VI})$ can reach $100 \%$ when the solution contains $15.0 \mathrm{mg} \cdot \mathrm{L}^{-1}$ of $\mathrm{Cr}(\mathrm{VI})$ at room temperature. In addition, the solution $\mathrm{pH}$ and the composites dosage can affect the removal efficiency of $\mathrm{Cr}(\mathrm{VI})$. The Langmuir isotherm is applicable to describe the removal process. The kinetic studies demonstrate that the removal of $\mathrm{Cr}(\mathrm{VI})$ is consistent with pseudosecond-order kinetic model.
\end{abstract}

\section{Introduction}

Water pollution caused by heavy metal ions, such as $\mathrm{Ni}(\mathrm{II})$, $\mathrm{Cr}(\mathrm{VI}), \mathrm{Mo}(\mathrm{VI})$, and $\mathrm{Pb}(\mathrm{II})$ in groundwater, is one of the most serious environmental problems. Among the toxic metal oxyanions, chromium is widely distributed and exists in the waste coming from paint industry, metal finishing, textile dyeing, electroplating, and leather tanning [1]. Chromium mainly exists as trivalent $[\mathrm{Cr}(\mathrm{III})]$ and hexavalent [Cr(VI)] form in the natural environment. Because of the low solubility, mobility, and the weak ability to oxidize other species, the toxicity of $\mathrm{Cr}(\mathrm{III})$ is much lower than $\mathrm{Cr}(\mathrm{VI})$ [2]. In contrast, $\mathrm{Cr}(\mathrm{VI})$ demonstrates the higher toxicity, which can produce mutagenic, teratogenic, and carcinogenic effects in biological systems by reacting with nucleic acids and other cellular components [3]. Due to high toxicity of $\mathrm{Cr}(\mathrm{VI})$, applying efficient methods to remove $\mathrm{Cr}(\mathrm{VI})$ from waste water is of great importance.
So far, various kinds of methods have been developed to reduce the harmful effects of $\mathrm{Cr}(\mathrm{VI})$, such as chemical extraction [4], reduction-precipitation [5], ion exchange [6], bioleaching process $[7,8]$, and biosorption $[9,10]$. Among these methods, adsorption holds the significant position due to its high removal efficiency, low energy demand, and less chemical investment [11-13]. In the past years, researchers have applied various adsorbents to remove $\mathrm{Cr}(\mathrm{VI})$ from waste water, such as activated carbons [14], zeolites [15, 16], clays [17], and nanomagnetic particles [18]. However, these adsorbents have many defects including low porosity, low surface area, and lack of functional groups [19], which is of great importance for an efficient adsorbent. Hence adsorbents with high porosity, large surface area, and high functionality need to be developed for efficient removal of $\mathrm{Cr}(\mathrm{VI})$.

Nanoscale zero-valent iron (NZVI) has been extensively applied to treat various contaminants in aqueous solution 
because of its low cost and strong reducing activity [2024]. Also, NZVI has demonstrated the excellent ability to remove $\mathrm{Cr}(\mathrm{VI})$ from waste water through the mechanism of reduction, adsorption, or coprecipitation. However, some serious drawbacks associated with the practical application of NZVI need considering. The severe aggregation of iron nanoparticles during preparation and storage as well as the agglomeration into micrometer particles after the reaction with $\mathrm{Cr}(\mathrm{VI})$ may cause the dramatic deterioration in the reactivity $[20,25]$. To conquer these issues, dispersing NZVI in supporting materials, such as activated carbon, polymers, clay minerals, and molecular sieves based on silica, is a promise solution. Because silica-based molecular sieves have a porous structure giving a large surface area and uniform pore sizes, which are of great importance for a good adsorbent, it has been greatly used as the potential support for the fabrication of efficient adsorbent. To date, for the fabrication of NZVI based adsorbents for $\mathrm{Cr}(\mathrm{VI})$ removal, porous silica such as SBA-15 [26-29] and MCM-41 [30-32] and silica fumes [33, 34 ] has been used as the matrix to support NZVI particles in order to minimize the aggregation and increase the reactivity of NZVI. However, this porous silica has relative small pores below $10 \mathrm{~nm}$. Whether larger pore size can promote the reactivity of NZVI is still unknown. What is more, NZVI in these composites is supported on the external surfaces of the supports rather than going into pores [26, 27, 30,33], which causes the underutilization of pores of the porous materials. Zero-valent iron nanoparticles inside the pores of ordered mesoporous silica have been successfully reported by other researchers $[28,29,31,34,35]$, but a hydrogen reduction process under a harsh and dangerous condition including explosive hydrogen and higher temperatures or a complicated "two solvents" reduction technique using toxic cyclohexane as solvent is in demand. Therefore, it is necessary to develop a facile method to disperse nanoscale zero-valent iron nanoparticles homogeneously inside the pores of the porous matrix under mild, safe, and green condition.

In this work, macroporous siliceous foams (MOSF) [36] with large pores of around $100 \mathrm{~nm}$ and high pore volumes were chosen as the support material to load ZVI nanoparticles for the preparation of efficient adsorbent for $\mathrm{Cr}(\mathrm{VI})$ removal. Nonionic block copolymers are used as the supramolecular template to synthesize MOSF materials via a facile supra-assembly approach. Appropriately modified MOSF can be applied in bioapplications, phosphate and arsenic adsorption [37-40]. In this paper, we have synthesized MOSF-supported nanoscale zero-valent iron composites (Mx-NZVI) simply by the direct reduction of $\mathrm{Fe}^{3+}$ ions in MOSF with $\mathrm{NaBH}_{4}$ at normal pressures and temperatures, where water was used as a green solvent. The final materials were tested for their applicability in the remediation of $\mathrm{Cr}(\mathrm{VI})$. The main objectives of this work are (1) to synthesize nanoscale zero-valent iron supported inside MOSF composites (Mx-NZVI) with different NZVI contents; (2) to characterize Mx-NZVI composites with TEM, SEM, XRD, XPS, nitrogen isotherms analysis, magnetization measurements, and so on; (3) to evaluate $\mathrm{Cr}(\mathrm{VI})$ adsorption performance of Mx-NZVI composites; (4) to study the possible mechanism for the removal of $\mathrm{Cr}(\mathrm{VI})$ using $\mathrm{Mx}-\mathrm{NZVI}$ composites.

\section{Materials and Methods}

2.1. Materials. The following reagents were used as purchased without further purification: $\mathrm{EO}_{20} \mathrm{PO}_{70} \mathrm{EO}_{20}$ (denoted as $\mathrm{P} 123$, where EO is poly(ethylene oxide) and $\mathrm{PO}$ is poly(propylene oxide)) was purchased from Sigma-Aldrich. Tetramethyl orthosilicate (TMOS) was purchased from Energy Chemical (Shanghai, China). Other chemicals were purchased from Kelong Chemical Reagents Factory (Chengdu, China).

2.2. Synthesis of MOSF. MOSF was synthesized at $35^{\circ} \mathrm{C}$ in a $\mathrm{pH}=5.0$ buffer solution with $\mathrm{P} 123$ as the template according to the method reported previously [36]. Briefly, at $35^{\circ} \mathrm{C}, \mathrm{P} 123$ $(1 \mathrm{~g})$ and $\mathrm{Na}_{2} \mathrm{SO}_{4}(1.7 \mathrm{~g}, 0.40 \mathrm{M})$ were dissolved in $\mathrm{pH}=5.0$ NaAc-HAc $($ Ac = acetate $)$ buffer solution $(30 \mathrm{~g})\left(C_{t}=0.04 \mathrm{M}\right.$, where $\left.C_{t}=C_{\mathrm{NaAc}}+C_{\mathrm{HAc}}\right)$ to form a homogeneous solution under stirring. To this solution mixture, TMOS (1.52 g) was added under stirring. After 5 minutes, the stirring was stopped. The resultant mixture was kept in a static condition for $24 \mathrm{~h}$ and then hydrothermally treated at $100^{\circ} \mathrm{C}$ for another $24 \mathrm{~h}$. The white precipitates were filtered, repeatedly washed with water to remove the inorganic salts, and then dried at room temperature. The final MOSF products were obtained by calcination at $550^{\circ} \mathrm{C}$ for $5 \mathrm{~h}$ at heating steps of $2^{\circ} \mathrm{C} \cdot \mathrm{min}^{-1}$.

\subsection{Preparation of MOSF-Supported Nanoscale Zero-Valent} Iron Composites (Mx-NZVI). MOSF-supported nanoscale zero-valent iron was synthesized according to a protocol reported by Petala [30]. Briefly, MOSF ( $0.2 \mathrm{~g})$ was dispersed in absolute ethanol ( $5 \mathrm{~g})$, followed by the addition of a $10 \mathrm{wt} \%$ ethanolic solution $(0.5,1.0$, and $1.5 \mathrm{~g})$ containing $\mathrm{FeCl}_{3} \cdot 6 \mathrm{H}_{2} \mathrm{O}$. The mixture was heated at $45^{\circ} \mathrm{C}$ to evaporate the solvent, and then the obtained powder was dispersed in $5 \mathrm{~mL}$ of absolute ethanol again. The reducing agent was prepared by dissolving $\mathrm{NaBH}_{4}(0.56,0.112$, and $0.168 \mathrm{~g})$ in $50 \mathrm{~mL}$ of deionized water and was added drop-wise to the MOSF-Fe ${ }^{3+}$ solution while swirling by hand. The mixture was filtered and washed with water once and absolute ethanol three times and then dried in vacuum oven overnight. The weight percentage of iron in the final product was calculated to be $4.31,8.30$, and $12.8 \mathrm{wt} \%$ according to the results of AAS (see Characterization), denoted Ma-NZVI, Mb-NZVI, and McNZVI, respectively.

2.4. Characterization. The $2 \theta \mathrm{X}$-ray powder diffraction data (XRD) were collected with a DX-1000 CSC diffraction instrument at $40 \mathrm{kV}$ and $25 \mathrm{~mA}$. The scanning scope and scanning speed were in the $2 \theta$ range from 5 to $80^{\circ}$, in steps of $3^{\circ}$ per min. Scanning electron microscopy (SEM) images of $\mathrm{Mx}-$ NZVI were taken using a Navo NanoSEM 450 field-emission scanning electron microscope operated at $5 \mathrm{KV}$. X-ray photoelectron spectroscopy (XPS) measurements were performed with an AXIS UltraDLD (KRATOS). The linear background was subtracted from all spectra. $\mathrm{N}_{2}$ adsorption-desorption isotherms were measured on a Quantachrome NOVA 1000e surface area analyzer after degassing the samples at $180^{\circ} \mathrm{C}$ for 6 hours. The pore volume was calculated from the adsorption isotherms using BJH (Barrett-Joyner-Halenda) method. To determine the actual iron content loaded on the 
samples, the composites were extracted by diluted hydrofluoric acid and nitric acid. Obtained solution was analyzed by Atomic Absorption Spectroscopy (AAS) using SpectrAA 220FS. Magnetization $(M)$ measurements were performed on a superconducting quantum interference device (SQUID) magnetometer (MPMS VSM). Magnetic hysteresis loops were characterized at temperature of $300 \mathrm{~K}$ in external applied magnetic fields $(B)$ ranging from -7 to $+7 \mathrm{~T}$.

2.5. Batch Experiments for the Reduction of Cr(VI). Cr(VI) adsorption isotherms were acquired through batch experiments. $\mathrm{K}_{2} \mathrm{Cr}_{2} \mathrm{O}_{7}$ was selected as the source of $\mathrm{Cr}(\mathrm{VI}) .0 .03 \mathrm{~g}$ of $\mathrm{Mx}-\mathrm{NZVI}$ was added to $30 \mathrm{~mL}$ of $\mathrm{K}_{2} \mathrm{Cr}_{2} \mathrm{O}_{7}$ water solution (concentration of $\mathrm{Cr}(\mathrm{VI}): 3,6,9,12,15 \mathrm{mg} \cdot \mathrm{L}^{-1}$ ) followed by shaking $(200 \mathrm{rpm})$ at $25^{\circ} \mathrm{C}$ for $24 \mathrm{~h}$. The initial $\mathrm{pH}$ of the suspension was adjusted to 2 by $0.1 \mathrm{M} \mathrm{HCl}$ or $\mathrm{NaOH}$ solution. To explore the effect of coexisting cations on $\mathrm{Cr}(\mathrm{VI})$ removal, $100 \mathrm{mg} \cdot \mathrm{L}^{-1}$ of each cations was added to $15 \mathrm{mg} \cdot \mathrm{L}^{-1}$ of $\mathrm{Cr}(\mathrm{VI})$ solution without adjusting $\mathrm{pH}$, respectively. After shaking, the suspension was filtered through a $0.45 \mu \mathrm{m}$ membrane filter. The $\mathrm{Cr}(\mathrm{VI})$ concentration of the solution was then determined by using the 1,5-diphenylcarbazide method [41].

All adsorption isotherm data were fitted with Langmuir isotherm model and Freundlich isotherm mode. The mathematical description of Langmuir isotherm model is given below [42]:

$$
q_{\mathrm{eq}}=\frac{b Q_{\mathrm{max}} C_{\mathrm{eq}}}{1+b C_{\mathrm{eq}}},
$$

where $q_{\mathrm{eq}}$ is the adsorption capacity at equilibrium $\left(\mathrm{mg} \cdot \mathrm{g}^{-1}\right)$, $C_{\mathrm{eq}}$ is residual metal ion concentration at equilibrium $\left(\mathrm{mg} \cdot \mathrm{L}^{-1}\right), \mathrm{Q}_{\max }\left(\mathrm{mg} \cdot \mathrm{g}^{-1}\right)$ is the maximum adsorption amount of metal ion per gram of adsorbent, and $b$ is a constant related to the energy or net enthalpy of adsorption $\left(\mathrm{L} \cdot \mathrm{mg}^{-1}\right)$.

The Freundlich isotherm explains the adsorption on a heterogeneous surface with uniform energy. This equation has the following form as

$$
q_{e}=K C_{e}^{1 / n}
$$

where $K$ and $n$ are the Freundlich constants, which are related to adsorption capacity and strength, respectively.

The adsorption kinetic experiments were performed by adding a given mass of Mx-NZVI to $50 \mathrm{~mL}$ of $\mathrm{K}_{2} \mathrm{Cr}_{2} \mathrm{O}_{7}$ solution with the concentration of $15 \mathrm{mg} \cdot \mathrm{L}^{-1}$ followed by shaking $(200 \mathrm{rpm})$ at $25^{\circ} \mathrm{C}$ for $24 \mathrm{~h}$. The initial $\mathrm{pH}$ of the suspension was adjusted to 2,5 , and 8 . During the reaction, at different periods, aliquots of the under study suspension were taken at certain time intervals. After filtration, the $\mathrm{Cr}(\mathrm{VI})$ concentration was analyzed. The contact time $(t)$ was calculated after the addition of adsorbent into the solution.

In order to investigate the mechanism of absorption and potential rate controlling step, the pseudo-first-order and the pseudo-second-order kinetic model were used to fit experimental data. The Lagergren first-order equation is generally expressed as

$$
\frac{d_{c}}{d_{t}}=-K_{\mathrm{obs}} C ;
$$

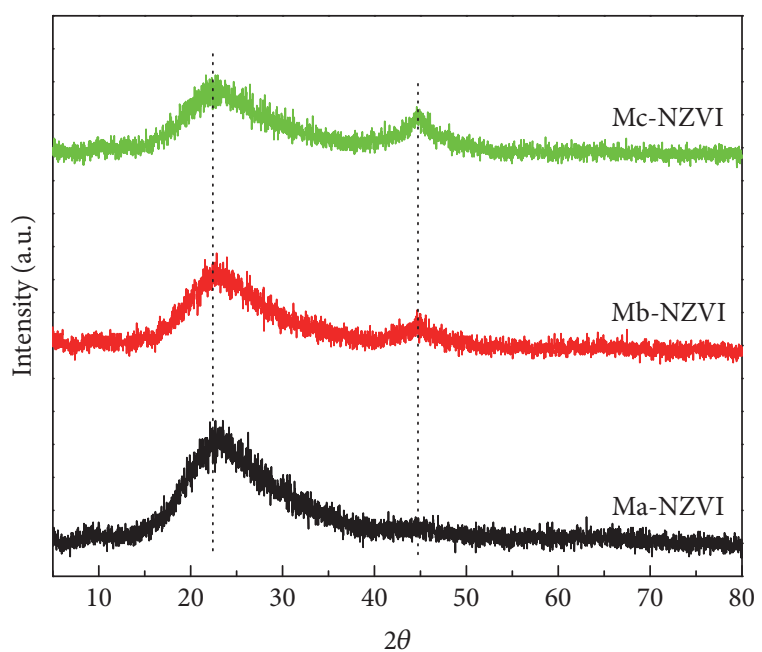

Figure 1: The wide-angle X-ray diffraction patterns of Mx-NZVI composites.

after integration of (3) with the boundary conditions as follows, $t=0, C=C_{0}$, and, at $t=t, C=C$, the integrated form is given as

$$
\ln \left(\frac{C}{C_{0}}\right)=-K_{\mathrm{obs}} t
$$

where $C_{0}$ and $C$ express $\mathrm{Cr}(\mathrm{VI})$ concentration in the solution at time 0 and $t$ and $k_{\text {obs }}$ is the rate constant of the pseudo-firstorder reaction $\left(\mathrm{min}^{-1}\right)$. The values of were linearly correlated with $t$. The straight-line plots of against $t$ should give a linear relationship, from which rate constants $\left(K_{\text {obs }}\right)$ can be determined from the slope and intercept of the plot.

The pseudo-second-order kinetic rate equation is expressed as

$$
\frac{d_{q_{t}}}{d_{t}}=k\left(q_{\mathrm{eq}}-q_{t}\right)^{2}
$$

where $q_{\mathrm{eq}}$ is the sorption capacity at equilibrium $\left(\mathrm{mg} \cdot \mathrm{g}^{-1}\right), q_{t}$ is the amount adsorbed at a contact time $t\left(\mathrm{mg}^{-1} \mathrm{~g}^{-1}\right)$, and $k$ is the rate constant $\left(\mathrm{g} \cdot \mathrm{mg}^{-1} \cdot \mathrm{min}^{-1}\right) . k$ and $q_{\text {eq }}$ were calculated from the slope and intercept of the plots of $t / q_{t}$ versus $t$ according to equation:

$$
\frac{t}{q_{t}}=\frac{1}{k} q_{\mathrm{eq}}{ }^{2}+\frac{t}{q_{\mathrm{eq}}} .
$$

\section{Results and Discussion}

Figure 1 shows the wide-angle X-ray diffraction (XRD) patterns of Mx-NZVI $(x=a, b$, and $c$, where the weight percentage of iron is $4.31,8.30$, and $12.8 \%$, resp.; see Materials and Methods). Mx-NZVI composites with different iron loading amount have the similar diffraction patterns. The characteristic peak at $2 \theta \approx 22^{\circ}$ in the XRD patterns of samples indicates the presence of amorphous silica [39]. The peak 


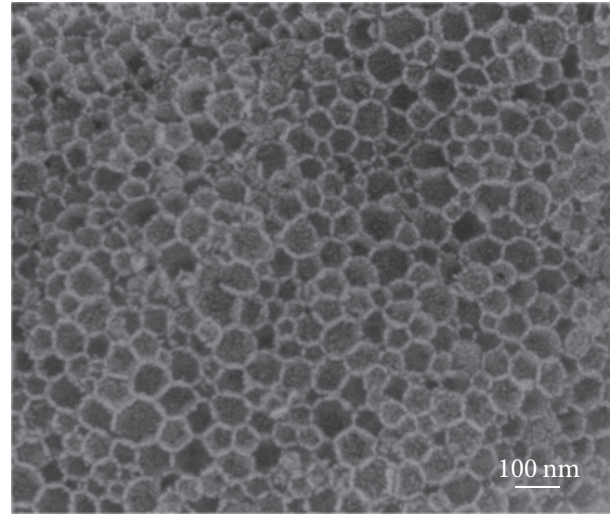

(a)

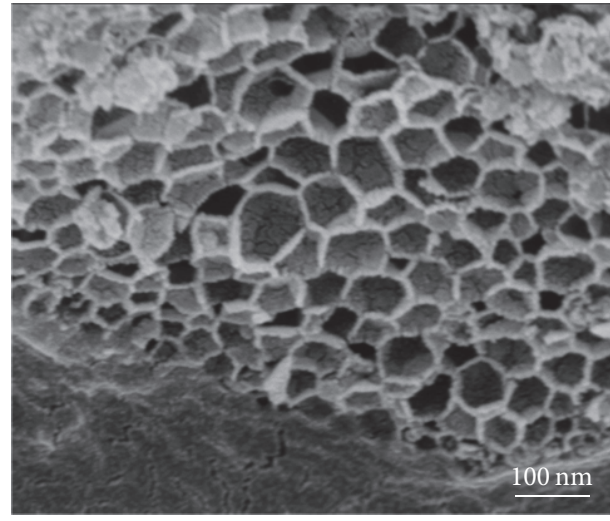

(c)

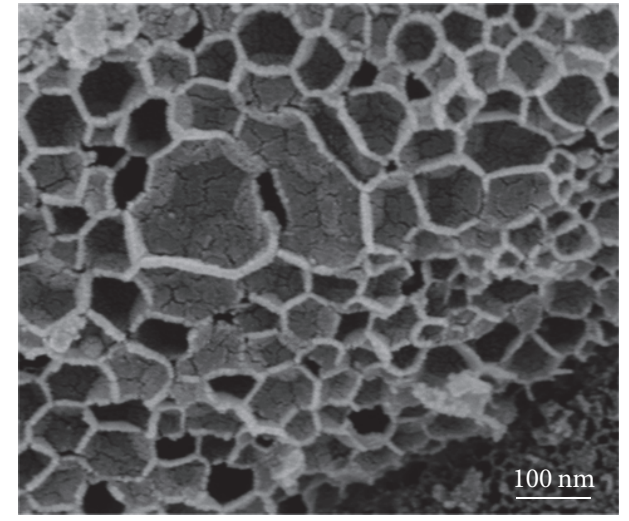

(b)

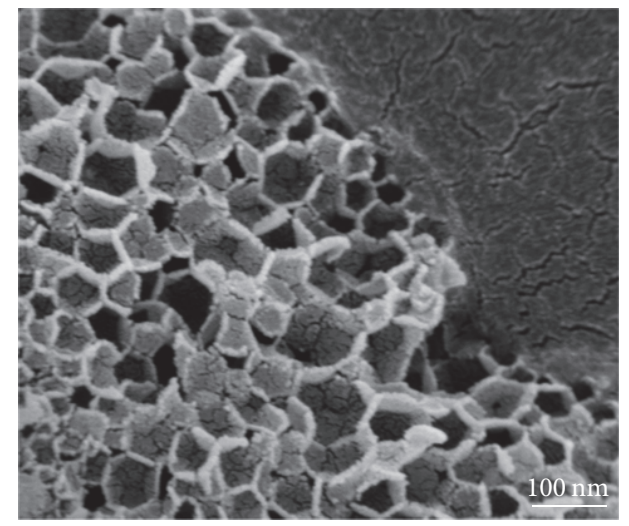

(d)

Figure 2: SEM images of MOSF (a), Ma-NZVI (b), Mb-NZVI (c), and Mc-NZVI(d), respectively.

intensity of amorphous silica weakens with increased loading amount of $\mathrm{Fe}^{0}$. Another peak at $2 \theta \approx 44.9^{\circ}$ can be indexed to the diffraction of $\mathrm{Fe}^{0}$ with the space group of $\operatorname{Im} \overline{3} m$ (JCPDS Card number 06-0696), indicating the presence of $\mathrm{Fe}^{0}$ in the MOSF matrix. The broad diffraction peak of $\mathrm{Fe}^{0}$ also demonstrates the small particle size of NZVI loaded in MOSF. Other diffractions due to the existence of iron oxides such as magnetite, $\gamma-\mathrm{Fe}_{2} \mathrm{O}_{3}$, or hematite are not observed in the XRD patterns of Mx-NZVI, which manifests iron predominantly in the $\mathrm{Fe}^{0}$ state.

From nitrogen sorption analysis, the BET surface areas, the pore sizes, and the total pore volumes of pristine MOSF and Mx-NZVI composites can be obtained. As shown in Figure S1, all samples show typical type II isotherms with relatively large hysteresis loops (see Figure S1 in Supplementary Material available online at https://doi.org/10.1155/2017/3094606). Besides, the capillary condensation occurs at relatively pressure $P / P_{0}$ higher than 0.9. Both can demonstrate the macroporous structure of MOSF and Mx-NZVI. The structural parameters of MOSF and Mx-NZVI are summarized in Table S1. The surface area and total pore volume of MOSF are $503 \mathrm{~m}^{2} \cdot \mathrm{g}^{-1}$ and $1.81 \mathrm{~cm}^{3} \cdot \mathrm{g}^{-1}$, respectively. With the increase of iron loading amount from $4.31 \%$ to $12.8 \%$, the surface area decreases from
379 to $311 \mathrm{~m}^{2} \cdot \mathrm{g}^{-1}$, and the pore volume reduces from 1.56 to $1.28 \mathrm{~cm}^{3} \cdot \mathrm{g}^{-1}$. Although after the loading of iron in MOSF, the pore size drops slightly from $124 \mathrm{~nm}$ (MOSF) to $117 \mathrm{~nm}$ (McNZVI), Mx-NZVI materials still maintain the macroporous structure. Such marcoporous structure with large pore size and high pore volume may benefit the fast diffusion and transportation of $\mathrm{Cr}(\mathrm{VI})$ ions during adsorption process.

The surface morphologies and structures of MOSF and Mx-NZVI were investigated by scanning electron microscope (SEM), as seen in Figure 2. SEM images of MOSF and MxNZVI clearly show uniform hexagonally arrayed columns in large scale. Few aggregated ZVI nanoscale particles can be observed on the surface of MOSF, which indicates most of the NZVI are loaded inside the pores of MOSF. Furthermore, TEM characterization demonstrates similar results to those of SEM. As displayed in Figure 3(a), pristine MOSF exhibits the foam-like structure packed by polyhedral units following a surface minimization principle [43]. The typical TEM images of Mc-NZVI at a low and a higher magnification are shown in Figures 3(b) and 3(c). Macropores of Mc-NZVI with the diameter of $\sim 100 \mathrm{~nm}$ can be clearly observed, indicating that the foam-like structure of MOSF can be well maintained after the loading of NZVI particles in MOSF. Besides, the homogeneous distribution of NZVI particles in MOSF (dark 


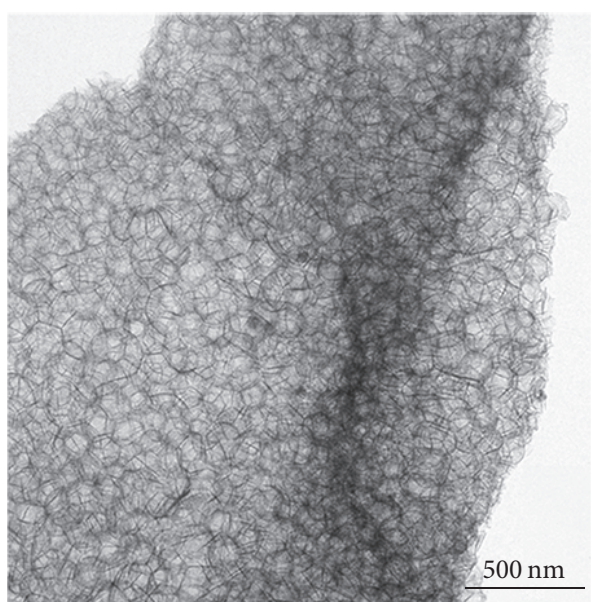

(a)

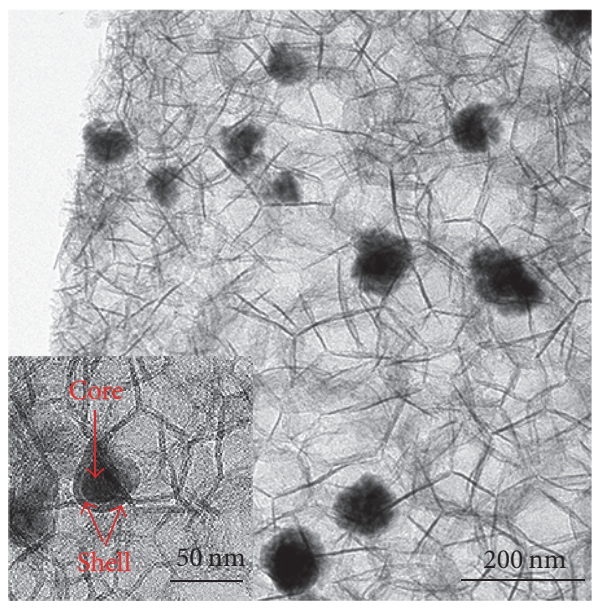

(c)

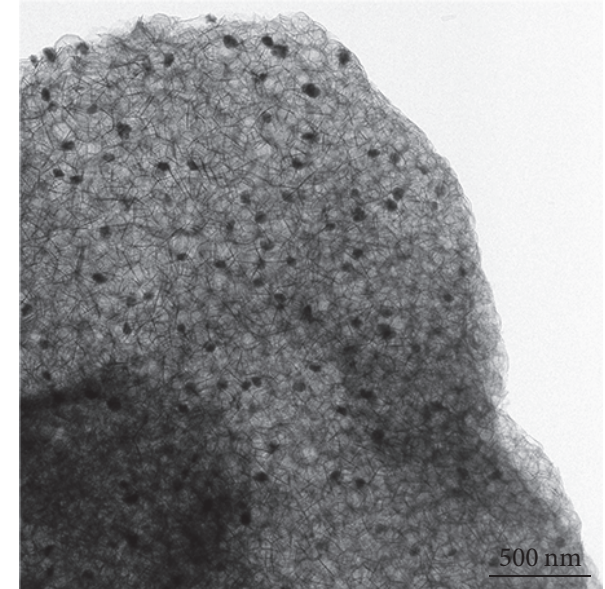

(b)

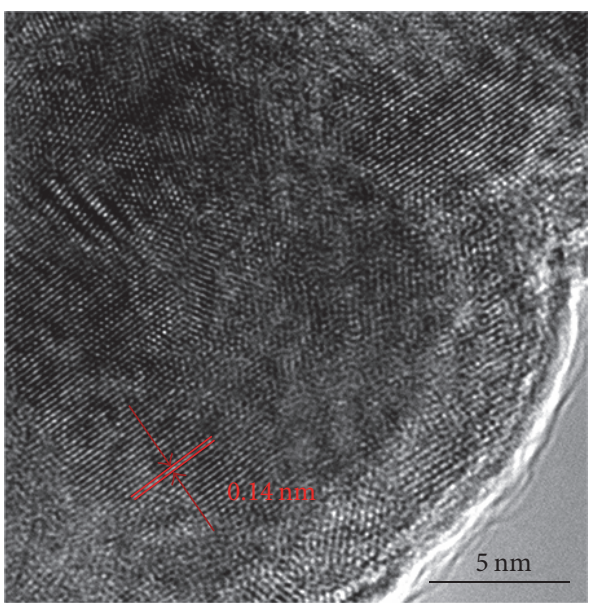

(d)

FIgURE 3: TEM images of MOSF (a) and Mc-NZVI at a low magnification (b). (c) and inset of (c) are TEM images of Mc-NZVI at higher magnification. (d) is the HRTEM image of ZVI nanoparticles.

dots with a high contrast in Figures 3(b) and 3(c)) without aggregation can be clearly seen through the whole sample. NZVI particles supported in MOSF have the elliptical shape with the size distribution of $20-120 \mathrm{~nm}$ according to the size distribution histogram of NZVI particles counted in Figure 3(b) (Supporting Information, Figure S2). Inset of Figure 3(c) shows TEM image of NZVI nanoparticles inside MOSF with higher resolution. NZVI nanoparticles possess a typical core-shell structure, in which the shell thickness is less than $10 \mathrm{~nm}$, similar to the previous observations. The core is mainly made up of $\mathrm{Fe}^{0}$ and the shell could result from the inevitable oxidation of zero-valent iron $[22,44,45]$. Figure $3(\mathrm{~d})$ is a typical high resolution TEM image of NZVI particles supported by MOSF, where the (200) lattice fringes of $\mathrm{Fe}^{0}$ can be clearly observed in the NZVI. TEM observation confirms that, with the supporting of MOSF matrix, the aggregation degree of NZVI particles can be minimized. Mx-NZVI composites with lower NZVI loading amount, namely, Ma-NZVI and Mb-NZVI, were also characterized by
TEM (Supporting Information, Figure S3). Due to the lower content of iron, the number of ZVI nanoparticles supported in MOSF is less compared with Mc-NZVI. Elemental maps of Mc-NZVI elucidate the homogeneous distribution of zerovalent iron nanoparticles in MOSF (Figure 4). Fe, Si, and O elements are found uniformly distributed and well correlated with the shape of the sample area.

To further confirm the successful loading of homogeneously dispersed NZVI particles in MOSF, XPS analysis was carried out. The survey spectrum of Mc-NZVI (Figure 5(a)) reveals the existence of $\mathrm{Fe}, \mathrm{O}, \mathrm{Si}$, and $\mathrm{C}$, in good agreement with the results of elemental maps. In Fe 2p (Figure 5(b)), a photoelectron peak appears at $707 \mathrm{eV}$, indicating the presence of $\mathrm{Fe}^{0}$ inside MOSF. It is noteworthy that two photoelectron peaks are located at $711.7 \mathrm{eV}$ and $725.4 \mathrm{eV}$, which can be assigned to the Fe $2 \mathrm{p}_{3 / 2}$ and $\mathrm{Fe} 2 \mathrm{p}_{1 / 2}$ for $\mathrm{Fe}(\mathrm{II})$ and $\mathrm{Fe}$ (III) species [22]. Such results are conflicting with the XRD results. From XRD analysis, the presence of $\mathrm{Fe}(\mathrm{II}) / \mathrm{Fe}(\mathrm{III})$ species inside MOSF cannot be detected, while, according to XPS 


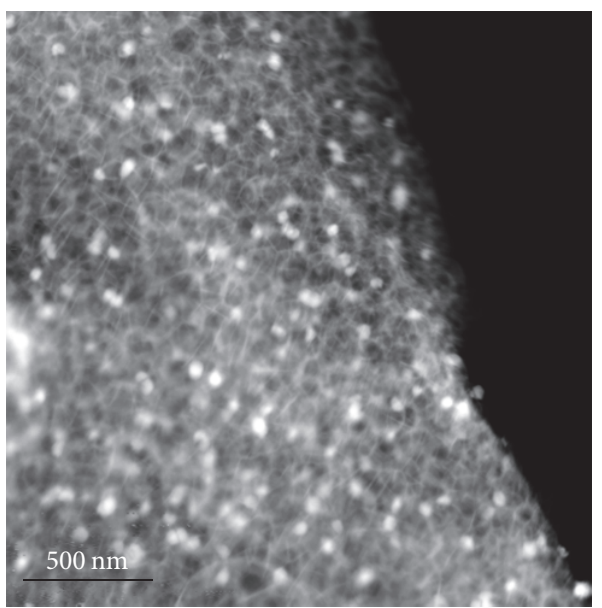

(a)

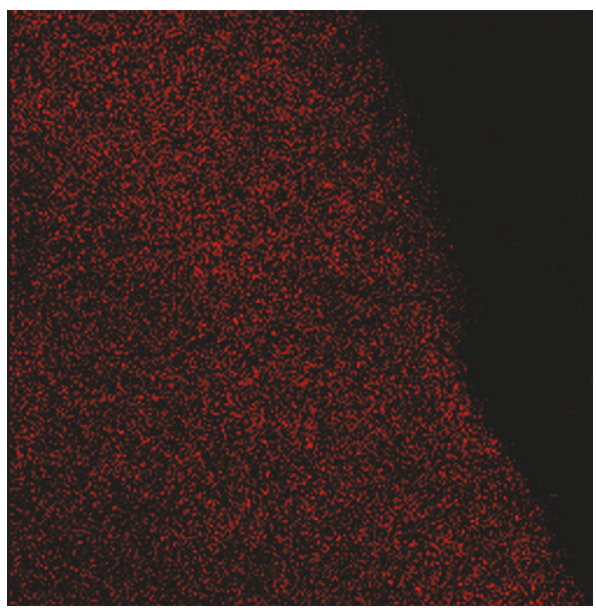

(c)

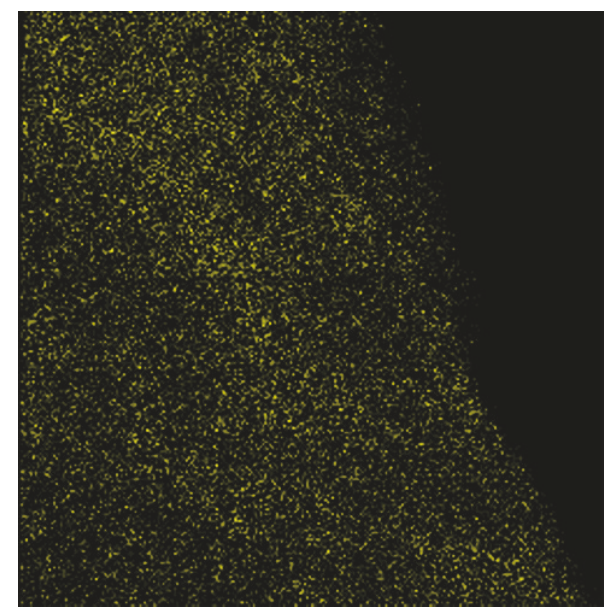

(b)

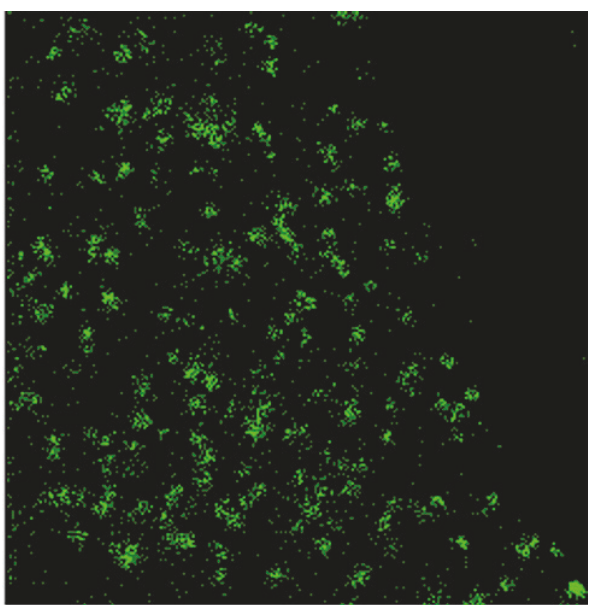

(d)

FigURE 4: DF-STEM image (a) and the corresponding $\mathrm{Si}(\mathrm{b}), \mathrm{O}(\mathrm{c})$, and Fe (d) elemental maps of Mc-NZVI.

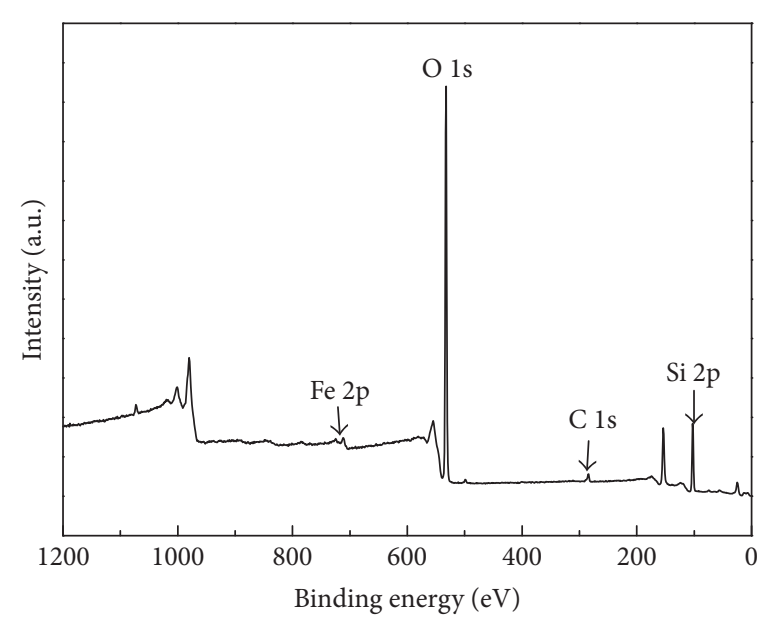

(a)

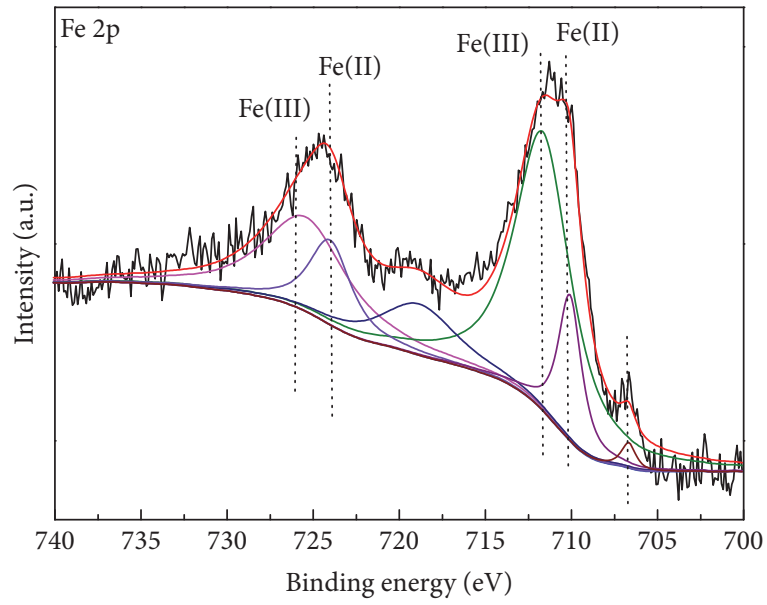

(b)

Figure 5: XPS spectra of the Mc-NZVI: (a) the survey scan and (b) Fe 2p. 


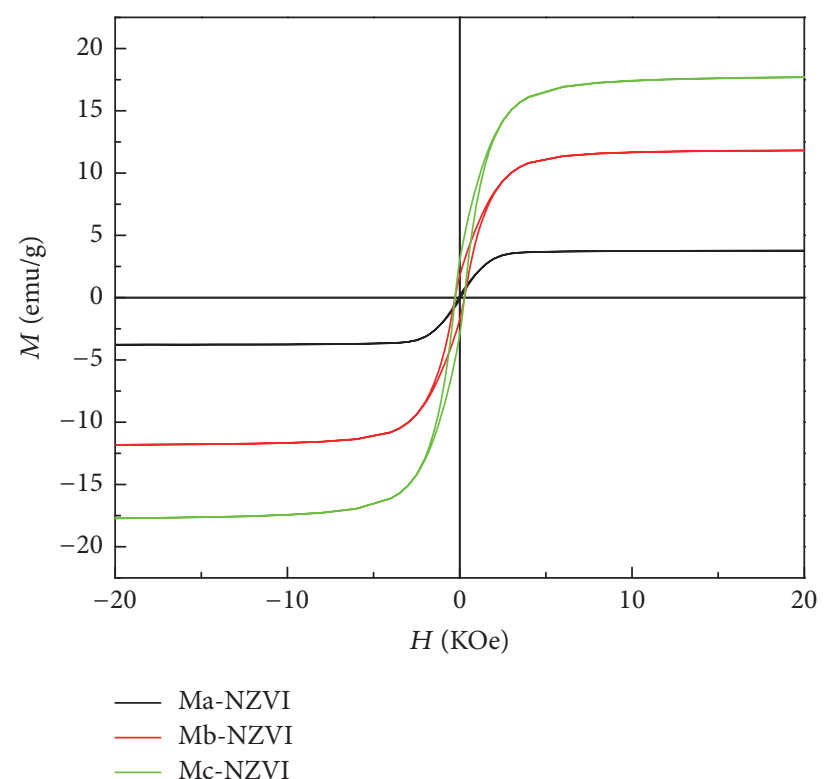

Figure 6: Hysteresis loops of Mx-NZVI composites recorded at $300 \mathrm{~K}$.

results, $\mathrm{Fe}(\mathrm{II}) / \mathrm{Fe}(\mathrm{III})$ species and $\mathrm{Fe}^{0}$ are both found in MOSF. Such conflict may be due to the amorphous nature of $\mathrm{Fe}(\mathrm{II}) / \mathrm{Fe}$ (III) species acting as shells around the NZVI, or because of the small amount that cannot be detected by XRD. Because the XPS analysis could only detect the photoelectrons from the outer surface with the thickness of $10 \mathrm{~nm}$, it is supposed that the thickness of the shell of $\mathrm{Fe}(\mathrm{II}) / \mathrm{Fe}(\mathrm{III})$ species around the ZVI nanoparticles could be less than $10 \mathrm{~nm}$ considering the appearance of $\mathrm{Fe}^{0}$ signal in the Fe $2 p$ spectrum [46]. According to the results of TEM, $\mathrm{XRD}$, and XPS, it can be concluded that NZVI nanoparticles inside the pores of MOSF have a core-shell structure, where the core is composed of NZVI and the shell is $\mathrm{Fe}(\mathrm{II}) / \mathrm{Fe}(\mathrm{III})$ species with the shell thickness of less than $10 \mathrm{~nm}$. The similar results are found in the XPS analysis for Ma-NZVI and MbNZVI (Supporting Information, Figure S4(a-b)).

Magnetization measurements were taken to reveal the physical properties of Mx-NZVI samples. Figure 6 shows the hysteresis loops of Mx-NZVI composites recorded at $300 \mathrm{~K}$. All samples show ferromagnetic or ferrimagnetic characteristics, corresponding to the metallic $\mathrm{Fe}^{0}$ or iron oxide phases. Saturation magnetization (Ms) at $20 \mathrm{KOe}$ is $\sim 3.77$ and 11.81 to $17.70 \mathrm{emu} / \mathrm{g}$ for Ma-NZVI, Mb-NZVI, and Mc-NZVI, which comes as a consequence of the hybrid-microstructured nature with the introduction of iron species. The hysteresis loops of Mb-NZVI and Mc-NZVI display coercivity (Hc) of about 0.275 and $0.278 \mathrm{kOe}$, which are higher than that of the Ma-NZVI (about $0.062 \mathrm{kOe}$ ), indicating the difference in the shell thickness of iron oxide and crystal size of iron core [46]. The magnetization with applied field shows smooth change in the hysteresis loops, suggesting that iron core and iron oxide shell were in intimate contact and exchange coupled [47].

The maximum adsorption capacities of the Mx-NZVI composites on hexavalent chromium removal were estimated by conducting a series of batch experiments. The $\mathrm{Cr}(\mathrm{VI})$ adsorption isotherms and the fitting results are demonstrated in Table S2. The adsorption data are slightly better fitted to Langmuir isotherm model (Figure 7(a)) than Freundlich isotherm model (Supporting Information, Figure S5a) because the coefficient $\left(R^{2}\right)$ for Langmuir isotherm model is higher. Such correlation results indicate the adsorption process of $\mathrm{Cr}(\mathrm{VI})$ occurs on the homogeneous surface of Mx-NZVI materials [40]. It is observed that the adsorption capacities of Mx-NZVI composites can be improved with increased iron loading amount. The maximum $\mathrm{Cr}(\mathrm{VI})$ adsorption capacities of Ma-NZVI, Mb-NZVI, and McNZVI are calculated to be $5.415,7.658$, and $12.665 \mathrm{mg} \cdot \mathrm{g}^{-1}$, respectively.

Figures 7(b) and 7(c) display the $\mathrm{Cr}(\mathrm{VI})$ adsorption kinetics of Mx-NZVI composites, and the kinetic parameters are summarized in Table S3. All the experimental data can be fitted to the pseudo-second-order kinetic model with a high correlation coefficient over 0.98 (Supporting Information, Figure S5(b-d)), suggesting that the sorption of $\mathrm{Cr}(\mathrm{VI})$ by $\mathrm{Mx}-\mathrm{NZVI}$ is mainly through chemisorption [48]. In addition, the pseudo-first-order model was also used to interpret the experimental data, but the fitting result was not very good as pseudo-second-order model (Supporting Information, Figure S6). It is noted that, in all kinetic experiments, a rapid removal rate of $\mathrm{Cr}(\mathrm{VI})$ is displayed during initial $3 \mathrm{~h}$, which hints that most of the adsorption sites exist on the surface of the adsorbent and are easily accessible by the $\mathrm{Cr}(\mathrm{VI})$ species [49]. Then, the removal rate slightly declines in the later adsorption stage. The rate declination can be explained as below. During the adsorption process, first $\mathrm{Cr}(\mathrm{VI})$ species in aqueous solution move to Mx-NZVI. Then, physical/chemical adsorption of $\mathrm{Cr}(\mathrm{VI})$ occurs on the surface of Mx-NZVI material. Finally, $\mathrm{Fe}^{0}$ is oxidized to $\mathrm{Fe}(\mathrm{III})$ and $\mathrm{Cr}(\mathrm{VI})$ is reduced by $\mathrm{Fe}^{0}$ to $\mathrm{Cr}(\mathrm{III})$, and precipitation of Cr(III) forms on the surface of Mx-NZVI [50]. The rate declination is caused by the formation of chromium oxide precipitates or $\mathrm{Fe}(\mathrm{III})-\mathrm{Cr}(\mathrm{III})$ hydroxides, which may exist as a thin layer on the surface of Mx-NZVI. The presence of thin layer prevents the electron transferring from NZVI to $\mathrm{Cr}(\mathrm{VI})$ and thus accordingly eliminates the following reduction of $\mathrm{Cr}(\mathrm{VI})$ to $\mathrm{Cr}(\mathrm{III})$ [44].

When the dosage of Mx-NZVI is $3 \mathrm{~g} \cdot \mathrm{L}^{-1}$ and the initial concentration of $\mathrm{Cr}(\mathrm{VI})$ is $15 \mathrm{mg} \cdot \mathrm{L}^{-1}$, the equilibrium can be reached after 500-700 min (Figure 7(b)). After $24 \mathrm{~h}$ adsorption, $48.28 \%$ of $\mathrm{Cr}(\mathrm{VI})$ can be removed by Ma-NZVI, while nearly $100 \%$ of $\mathrm{Cr}(\mathrm{VI})$ can be eliminated using Mc-NZVI. According to the rate constant which is related to removal rate of $\mathrm{Cr}(\mathrm{VI})$, Mc-NZVI with the highest rate constant of $0.0115 \mathrm{~g} \cdot \mathrm{mg} \cdot \mathrm{min}^{-1}$ exhibits the fastest $\mathrm{Cr}(\mathrm{VI})$ removal rate from water among three samples.

The effect of Mc-NZVI dosage (1.0 to $3.0 \mathrm{~g} \mathrm{~L}^{-1}$ ) on the adsorption kinetics of $\mathrm{Cr}(\mathrm{VI})$ with the initial concentration of $15.0 \mathrm{mg} \cdot \mathrm{L}^{-1}$ was investigated. As exhibited in Figure 7(c), the $\mathrm{Cr}(\mathrm{VI})$ removal efficiency increases significantly from $45.04 \%$ to nearly $100 \%$ as the dosage of Mc-NZVI grows from $1 \mathrm{~g} \cdot \mathrm{L}^{-1}$ to $3 \mathrm{~g} \cdot \mathrm{L}^{-1}$ in $24 \mathrm{~h}$. This phenomenon is attributed to the increase of the active sites on the surface of Mc-NZVI [51]. In 

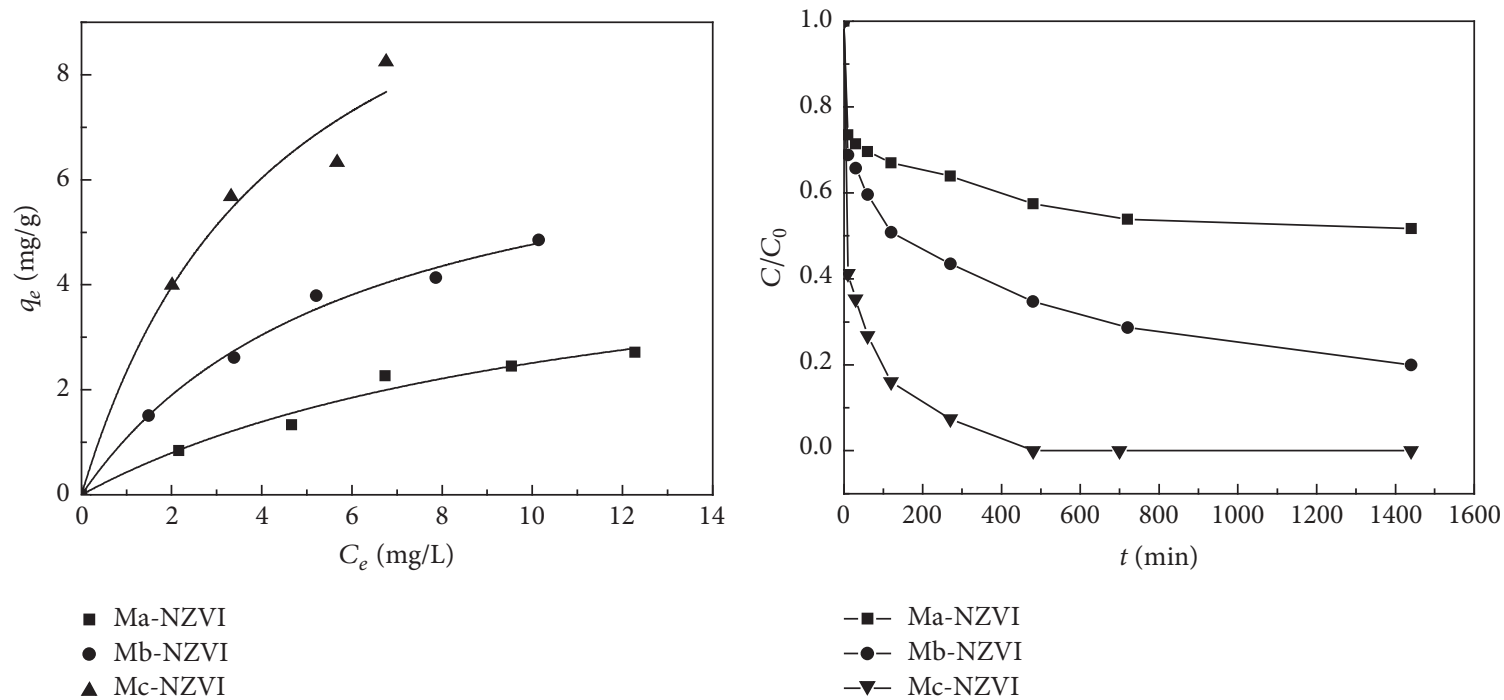

(a)
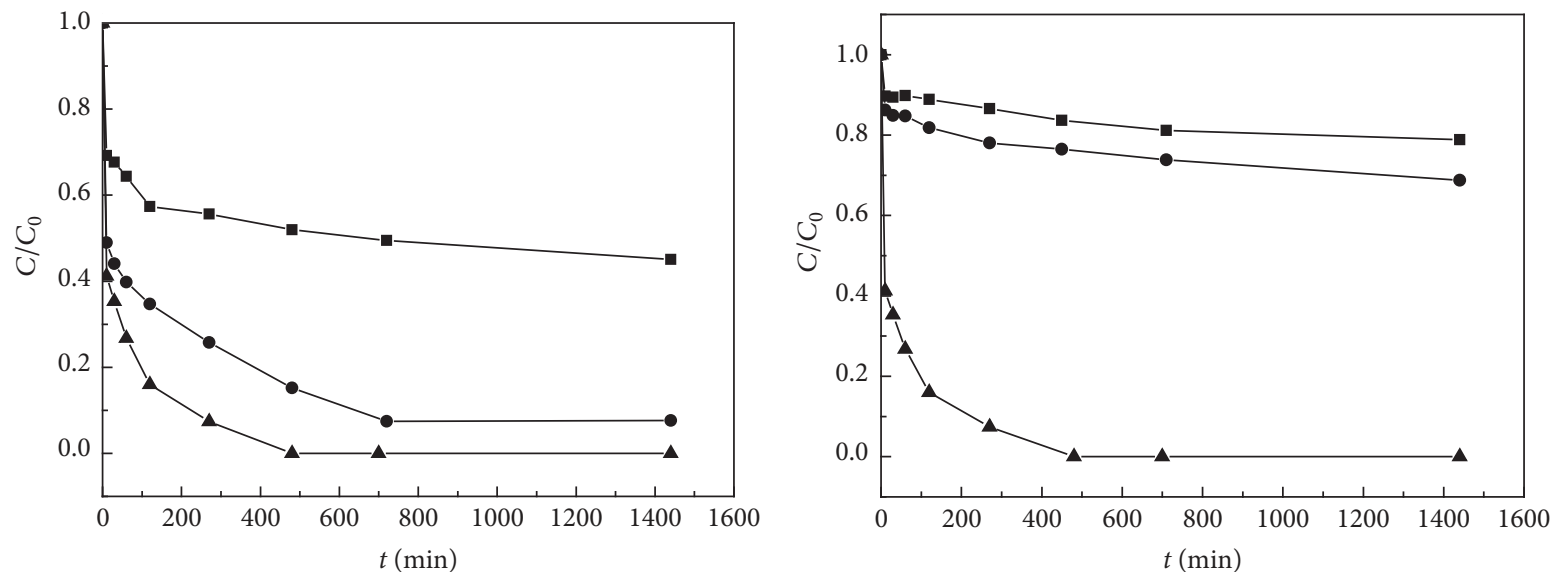

$$
\begin{aligned}
& -\square-1 \mathrm{~g} / \mathrm{L} \\
& -\bullet-2 \mathrm{~g} / \mathrm{L} \\
& -\mathbf{-}-3 \mathrm{~g} / \mathrm{L}
\end{aligned}
$$

(c)

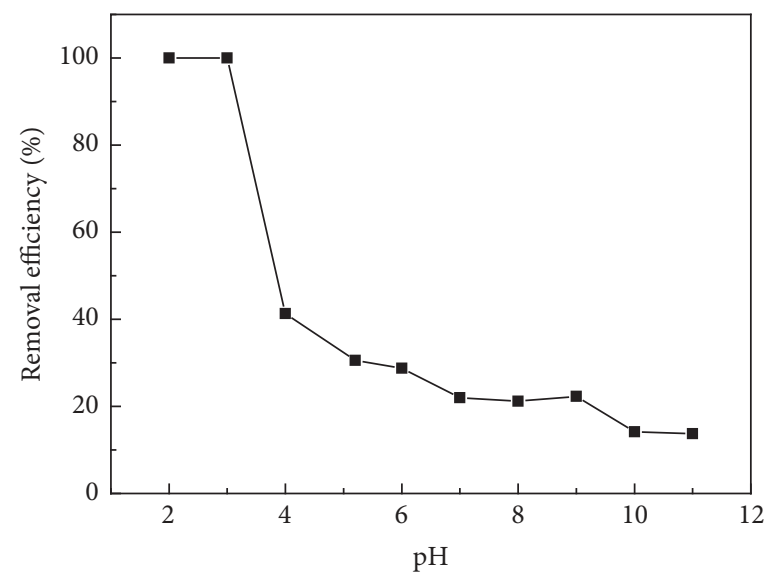

(e)

$-\mathbf{-}-\mathrm{pH}=2$

$-\bullet-\mathrm{pH}=5$

- $-\mathrm{pH}=8$

(d)

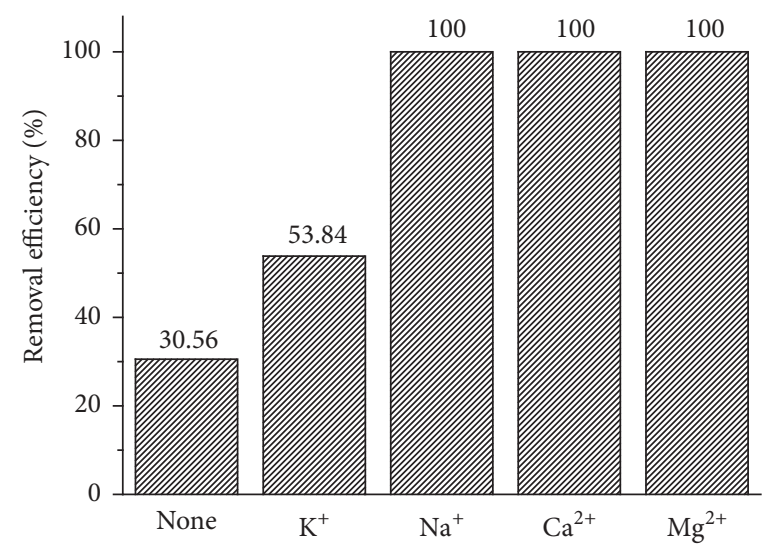

(f)

Figure 7: (a) Cr(VI) adsorption isotherms of Mx-NZVI composites; (b) adsorption kinetics of Mx-NZVI composites. (c) Adsorption kinetics of Mc-NZVI with different dosage. (d) Adsorption kinetics of Mc-NZVI at different initial pH. (e) $\mathrm{Cr}(\mathrm{VI})$ uptake of Mc-NZVI as a function of $\mathrm{pH}$. (f) The effect of coexisting cations on $\mathrm{Cr}(\mathrm{VI})$ adsorption capacity of Mc-NZVI. The initial $\mathrm{Cr}(\mathrm{VI})$ concentration is $15 \mathrm{mg} \cdot \mathrm{L}^{-1}$. 
addition, the adsorption rate of $\mathrm{Cr}(\mathrm{VI})$ is also enhanced with the increase of Mc-NZVI dosage. With the dosage changing from 1 to $3 \mathrm{~g} \cdot \mathrm{L}^{-1}$, the rate constants are 0.00304, 0.00381, and $0.01115\left(\mathrm{~g} \cdot \mathrm{mg} \cdot \mathrm{min}^{-1}\right)$, respectively. Apparently, the high dosage of Mc-NZVI is beneficial for the fast adsorption rate due to increment of active sites.

The dependence of the $\mathrm{Cr}(\mathrm{VI})$ removal efficiency on $\mathrm{pH}$ was investigated by adjusting the solution $\mathrm{pH}$ to 2,5 , and 8. The initial $\mathrm{Cr}(\mathrm{VI})$ concentration is $15 \mathrm{mg} \cdot \mathrm{L}^{-1}$ and the McNZVI dosage is $3.0 \mathrm{~g} \cdot \mathrm{L}^{-1}$. As shown in Figure $7(\mathrm{~d})$, the $\mathrm{Cr}(\mathrm{VI})$ removal efficiency decreases significantly with the increase of initial $\mathrm{pH}$. Only $21.16 \%$ of $\mathrm{Cr}(\mathrm{VI})$ is adsorbed at $\mathrm{pH} 8.0$ after $24 \mathrm{~h}$, while $100 \%$ of $\mathrm{Cr}(\mathrm{VI})$ can be removed within $24 \mathrm{~h}$ at $\mathrm{pH}$ 2.0. What is more, adsorption capacity of McNZVI at other higher $\mathrm{pH}$ has also been studied (Figure 7(e)). Removal efficiency was $100 \%$ at $\mathrm{pH} 2$ and 3 . When the $\mathrm{pH}$ was higher than 3, a sharp decrease can be clearly seen in the removal efficiency. Clearly, the acidity of the $\mathrm{Cr}(\mathrm{VI})$ solution has a major influence on the removal efficiency of $\mathrm{Cr}(\mathrm{VI})$, which can be explained by following points. On one hand, the reduction of $\mathrm{Cr}(\mathrm{VI})$ by $\mathrm{Fe}^{0}$ would produce hydroxyl ions. Under low $\mathrm{pH}$ condition, hydroxyl ions can be consumed by $\mathrm{H}^{+}$, leading to the much easier reaction between $\mathrm{Cr}(\mathrm{VI})$ and $\mathrm{Fe}^{0}$. This process can be clearly expressed by the following equations (7)-(9):

$$
\begin{gathered}
\mathrm{Fe}^{0}+2 \mathrm{H}^{+} \longrightarrow \mathrm{Fe}^{2+}+\mathrm{H}_{2} \uparrow \\
\mathrm{HCrO}_{4}{ }^{-}+3 \mathrm{Fe}^{2+}+7 \mathrm{H}^{+} \longrightarrow 3 \mathrm{Fe}^{3+}+\mathrm{Cr}^{3+}+4 \mathrm{H}_{2} \mathrm{O} \\
2 \mathrm{HCrO}_{4}{ }^{-}+3 \mathrm{Fe}^{0}+14 \mathrm{H}^{+} \longrightarrow 3 \mathrm{Fe}^{3+}+\mathrm{Cr}^{3+}+8 \mathrm{H}_{2} \mathrm{O}
\end{gathered}
$$

On the other hand, $\mathrm{pH}$ has an impact on the surface charge of Mc-NZVI and $\mathrm{Cr}(\mathrm{VI})$ species. In the $\mathrm{pH}$ range of $2-8$, the predominant species of $\mathrm{Cr}(\mathrm{VI})$ is negatively charged $\mathrm{HCrO}_{4}{ }^{-} / \mathrm{CrO}_{4}{ }^{2-}$ [52]. The lower initial $\mathrm{pH}$ of the solution can result in the surface of Mc-NZVI with more positive charge. Hence, in $\mathrm{pH}$ of 2 , the electrostatic interaction between $\mathrm{Cr}(\mathrm{VI})$ species and Mc-NZVI is much stronger compared with that in $\mathrm{pH}$ of 11. Accordingly, the $\mathrm{Cr}(\mathrm{VI})$ adsorption capacity of Mc-NZVI decreases with the increase of $\mathrm{pH}$ [53]. What is more, the solubility of $\mathrm{Fe}(\mathrm{III})-\mathrm{Cr}$ (III) coprecipitation existing as a thin layer around NZVI is very low when the $\mathrm{pH}$ of solution is comparatively high [54], providing resistance for the subsequent redox adsorption of $\mathrm{Cr}(\mathrm{VI})$ [30]. These explain why a lower $\mathrm{pH}$ environment benefits the $\mathrm{Cr}(\mathrm{VI})$ removal in aqueous solution.

The effect of common cations $\left(\mathrm{Na}^{+}, \mathrm{K}^{+}, \mathrm{Mg}^{2+}\right.$, and $\left.\mathrm{Ca}^{2+}\right)$ in ground water was also investigated without adjusting $\mathrm{pH}$. As shown in Figure 7(f), with the absence of coexisting cations, the removal efficiency was only $30.56 \%$. With the addition of $\mathrm{K}^{+}$, the removal efficiency can be enhanced to $53.84 \%$. The removal efficiency can be as high as $100 \%$ in the presence of $\mathrm{Na}^{+}, \mathrm{Mg}^{2+}$, and $\mathrm{Ca}^{2+}$. Obviously, the presence of cations can greatly improve the removal of $\mathrm{Cr}(\mathrm{VI})$ by McNZVI composites, indicating the applicability of Mx-NZVI composites in the removal of $\mathrm{Cr}(\mathrm{VI})$ in ground water.

To provide direct evidence to our explanation for possible adsorption and reduction mechanism of $\mathrm{Cr}(\mathrm{VI})$ with $\mathrm{Mx}-$ NZVI, the XPS analysis was carried out for Mc-NZVI after absorbing $\mathrm{Cr}(\mathrm{VI})\left(15 \mathrm{mg} \cdot \mathrm{L}^{-1}\right)$ at initial $\mathrm{pH} 2$ and $25^{\circ} \mathrm{C}$ in a powder mode. The survey spectrum (Figure $8(\mathrm{a})$ ) confirms coexistence of $\mathrm{Fe}, \mathrm{O}, \mathrm{Si}, \mathrm{Cr}$, and adventitious $\mathrm{C}$. Figure 8(b) shows the high resolution XPS spectra of Fe 2p of Mc-NZVI after $\mathrm{Cr}(\mathrm{VI})$ removal. The $\mathrm{Fe}$ species in the form of $\mathrm{Fe}^{0}$ cannot be detected because the NZVI particles are covered with the oxide layer and/or $\mathrm{Fe}(\mathrm{III})-\mathrm{Cr}$ (III) coprecipitation, which hinder the reaction process. The XPS scan of the $\mathrm{Cr}$ $2 \mathrm{p}$ region is shown in Figure $8(\mathrm{c})$ with $\mathrm{Cr} 2 \mathrm{p}_{1 / 2}$ and $\mathrm{Cr} 2 \mathrm{p}_{3 / 2}$ lining at 586.0 and $576.7 \mathrm{eV}$ for $\mathrm{Cr}(\mathrm{III})$, respectively. It can be confirmed that $\mathrm{Cr}(\mathrm{VI})$ is reduced to $\mathrm{Cr}(\mathrm{III})$ by NZVI particles on the surface of the sample. The peak positions of $\operatorname{Cr} 2 \mathrm{p}_{1 / 2}$ and $\mathrm{Cr} 2 \mathrm{p}_{3 / 2}$ for $\mathrm{Cr}(\mathrm{VI})$ are comparatively higher located at 587.9 and $579.0 \mathrm{eV}[22,28,55]$. According to the quantitative curve fitting to the individual peak areas of $\mathrm{Cr}$ $2 \mathrm{p}$ peaks, about $70 \%$ of the chromium species has been reductive transformation into $\mathrm{Cr}(\mathrm{III})$ on the surface of $\mathrm{Mx}$ NZVI. After the reduction of $\mathrm{Fe}^{0}, \mathrm{Cr}$ (III) and $\mathrm{Fe}$ (III) form a thin layer of $\mathrm{Fe}(\mathrm{III})-\mathrm{Cr}$ (III) hydroxides on the outer surface of ZVI nanoparticles. Aforementioned date imply that the adsorption of $\mathrm{Cr}(\mathrm{VI})$ is based on both chemisorption and chemical reduction processes, and chemical reduction played a main role.

In light of the aforementioned results, we hypothesize that the removal of $\mathrm{Cr}(\mathrm{VI})$ by $\mathrm{Mx}-\mathrm{NZVI}$ composites may go through the reduction or/and precipitation processes. When $\mathrm{Cr}(\mathrm{VI})$ species in the solution diffuse into the pores of Mx-NZVI and are absorbed on the surfaces of the NZVIs, $\mathrm{Cr}(\mathrm{VI})$ is reduced to $\mathrm{Cr}(\mathrm{III})$ by NZVI inside the macropores $[28,52]$. Such reduction process could proceed via direct or indirect pathway as shown in Figure 9. The direct pathway can be described by the reduction of $\mathrm{Cr}(\mathrm{VI})$ to $\mathrm{Cr}(\mathrm{III})$ due to the electron transfer from $\mathrm{Fe}^{0}$ core, coupled with direct oxidation of $\mathrm{Fe}^{0}$ to $\mathrm{Fe}(\mathrm{III})$. Meanwhile, another indirect pathway presents the reduction reaction between $\mathrm{Cr}(\mathrm{VI})$ and $\mathrm{Fe}(\mathrm{II})[22,50]$. These active $\mathrm{Fe}(\mathrm{II})$ species derive from the electron transfer of $\mathrm{Fe}^{0}$ species, expressed by the following equations:

$$
\begin{gathered}
\mathrm{Fe}-2 \mathrm{e} \longrightarrow \mathrm{Fe}^{2+} \\
\mathrm{Fe}+2 \mathrm{Fe}^{3+} \longrightarrow 3 \mathrm{Fe}^{2+}
\end{gathered}
$$

In the precipitation process, $\left(\mathrm{Cr}_{x} \mathrm{Fe}_{1-x}\right)(\mathrm{OH})_{3}$ or $\mathrm{Cr}_{x} \mathrm{Fe}_{1-x} \mathrm{OOH}$ precipitates could form through the reaction of $\mathrm{Cr}$ (III) and Fe (III). Such precipitates are coated on the surface of NZVI as a passive layer [50], causing the gradual increase in the resistance of electron transform from $\mathrm{Fe}^{0}$ to $\mathrm{Cr}(\mathrm{VI})$. As a result, $\mathrm{Cr}(\mathrm{VI})$ species retain on $\mathrm{Fe}(\mathrm{III}) / \mathrm{Cr}(\mathrm{III})$ hydroxide layer on the surface of Mx-NZVI rather than being reduced to $\mathrm{Cr}(\mathrm{III})$ [55]. 


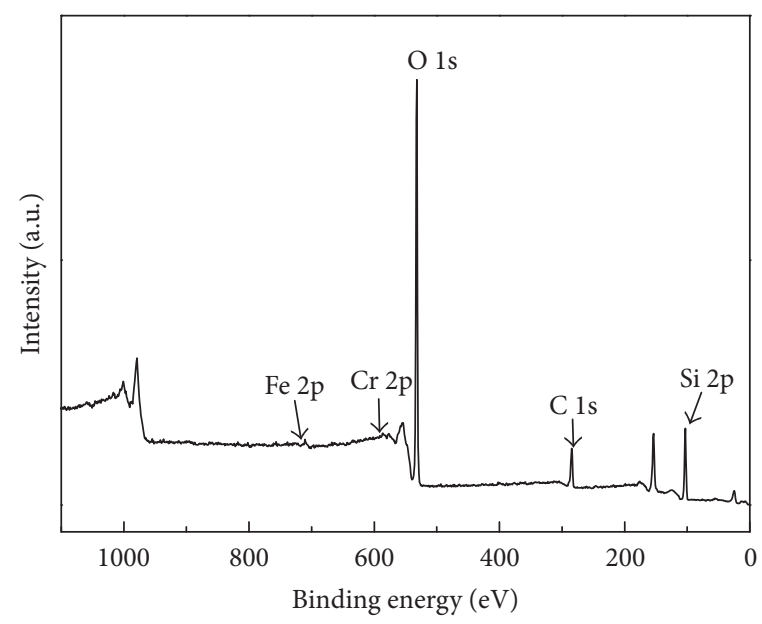

(a)

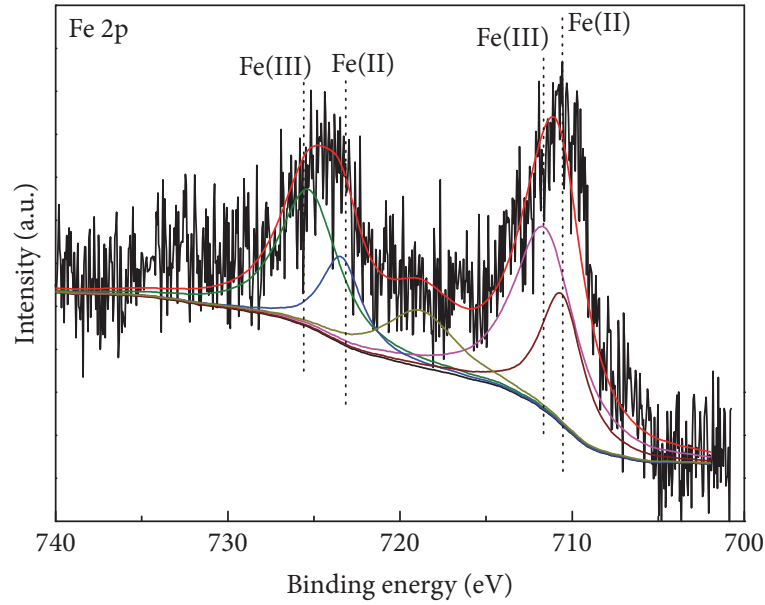

(b)

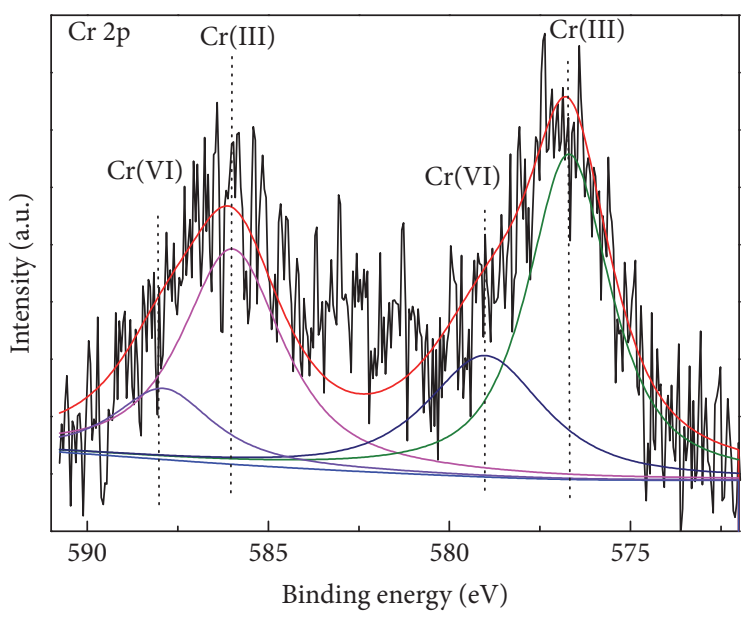

(c)

FIGURE 8: XPS spectra of the Cr(VI)-adsorbed Mc-NZVI. (a) is the survey, (b) is Fe 2p, and (c) is Cr 2p spectra of Cr(VI)-adsorbed Mc-NZVI.

\section{Conclusion}

In this study, well-dispersed nanoscale zero-valent iron supported in macroporous silica foams composites as the efficient $\mathrm{Cr}(\mathrm{VI})$ adsorbents has been fabricated and characterized. Through the support of MOSF matrix with large surface area and high pore volume, the reactivity and stability of Mx-NZVI composites were improved due to the prevention of aggregation of NZVI. NZVI nanoparticles inside MOSF showed a typical core-shell architecture, in which the core mainly consisted of $\mathrm{Fe}^{0}$ and the thin shell (less than $10 \mathrm{~nm}$ ) is largely made of $\mathrm{Fe}(\mathrm{II}) / \mathrm{Fe}$ (III) species. Mx-NZVI composites with macroporous structure and homogeneously dispersed NZVI particles in nanoscale range $(20-120 \mathrm{~nm})$ exhibited the good $\mathrm{Cr}(\mathrm{VI})$ adsorption performance. Batch experiments showed the composites were efficient adsorbents for the fast removal of $\mathrm{Cr}(\mathrm{VI})$ from aqueous solution. The kinetic data were well fitted to pseudo-second-order kinetic model, implying a chemisorption process. The adsorption capacities increased as the Mc-NZVI dosage and NZVI loading amount increased and fell as $\mathrm{pH}$ increased. It was also observed that the adsorption of $\mathrm{Cr}(\mathrm{VI})$ was fitted well on the Langmuir isotherm equilibrium. However, further experiments are still needed to investigate the remove process in real waste water and for other contaminants.

\section{Conflicts of Interest}

The authors declare that they have no conflicts of interest.

\section{Acknowledgments}

This work was financially supported by the National Natural Science Foundation of China (Grant no. 51502181). The 

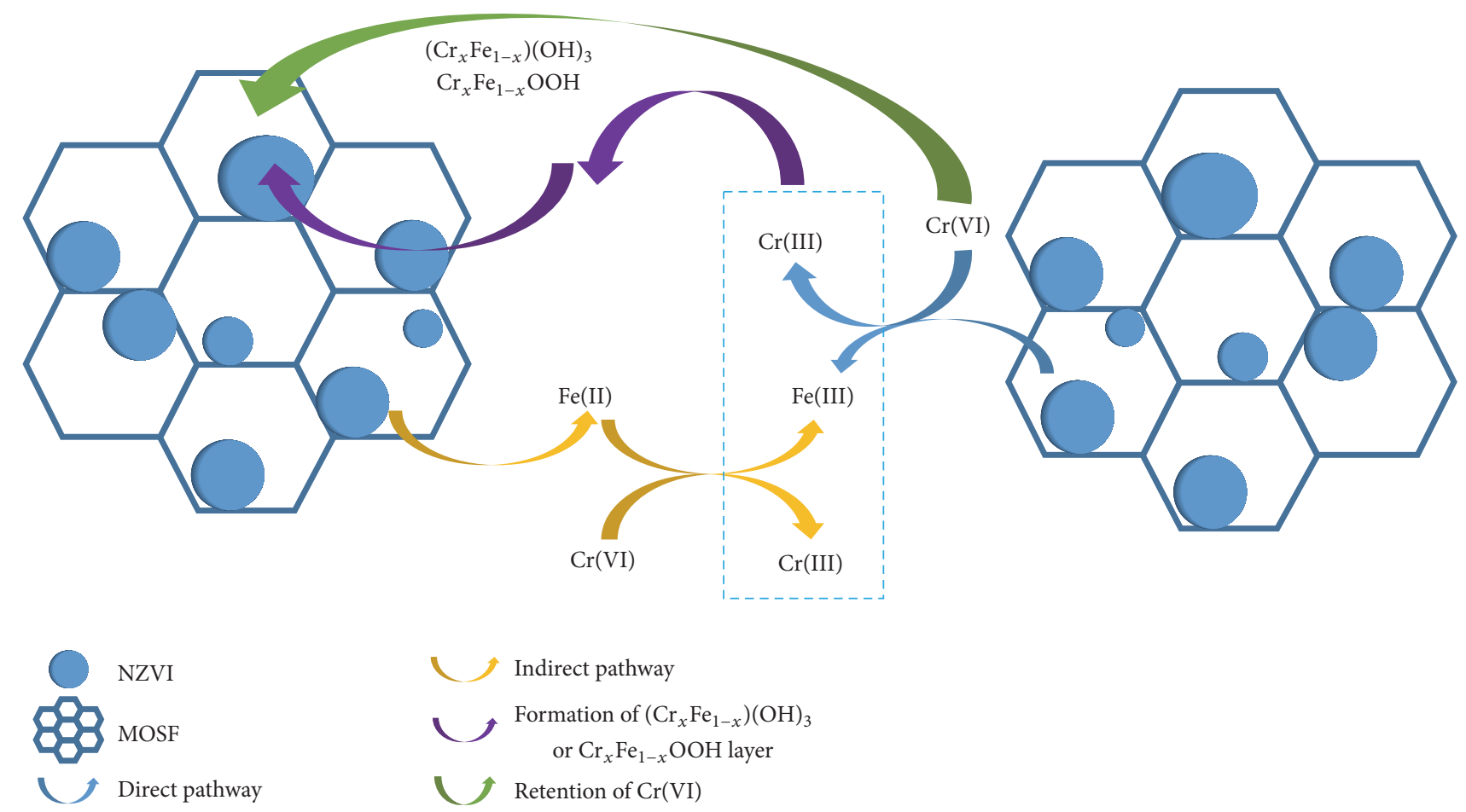

FIGURE 9: Schematic illustration of $\mathrm{Cr}(\mathrm{VI})$ removal mechanism by Mx-NZVI composites.

authors acknowledge the support from Experimental Testing Center College of Chemistry, Sichuan University, and Analytical \& Testing Center, Sichuan University, for sample analysis.

\section{References}

[1] S. Avudainayagam, M. Megharaj, G. Owens, R. S. Kookana, D. Chittleborough, and R. Naidu, "Chemistry of chromium in soils with emphasis on tannery waste sites," Reviews of Environmental Contamination and Toxicology, vol. 178, pp. 53-91, 2003.

[2] L. Zhang, W. Xia, X. Liu, and W. Zhang, "Synthesis of titanium cross-linked chitosan composite for efficient adsorption and detoxification of hexavalent chromium from water," Journal of Materials Chemistry A, vol. 3, no. 1, pp. 331-340, 2014.

[3] Y. Ishibashi, C. Cervantes, and S. Silver, "Chromium reduction in Pseudomonas putida," Applied and Environmental Microbiology, vol. 56, no. 7, pp. 2268-2270, 1990.

[4] P. J. C. Favas, J. Pratas, M. E. P. Gomes, and V. Cala, "Selective chemical extraction of heavy metals in tailings and soils contaminated by mining activity: Environmental implications," Journal of Geochemical Exploration, vol. 111, no. 3, pp. 160-171, 2011.

[5] E. Sahinkaya and A. Kilic, "Heterotrophic and elemental-sulfurbased autotrophic denitrification processes for simultaneous nitrate and Cr(VI) reduction," Water Research, vol. 50, pp. 278286, 2014.

[6] J.-H. Chen, K.-C. Hsu, and Y.-M. Chang, "Surface modification of hydrophobic resin with tricaprylmethylammonium chloride for the removal of trace hexavalent chromium," Industrial and Engineering Chemistry Research, vol. 52, no. 33, pp. 11685-11694, 2013.
[7] H. Ma, J. Zhou, L. Hua, F. Cheng, L. Zhou, and X. Qiao, "Chromium recovery from tannery sludge by bioleaching and its reuse in tanning process," Journal of Cleaner Production, vol. 142, pp. 2752-2760, 2017.

[8] M. Qu, J. Chen, Q. Huang et al., "Bioremediation of hexavalent chromium contaminated soil by a bioleaching system with weak magnetic fields," International Biodeterioration \& Biodegradation, 2016.

[9] S. Nag, A. Mondal, N. Bar, and S. K. Das, "Biosorption of chromium (VI) from aqueous solutions and ANN modelling," Environmental Science and Pollution Research, vol. 24, no. 23, pp. 1-9, 2017.

[10] J. Zhao, X. Zhang, X. He, M. Xiao, W. Zhang, and C. Lu, "A super biosorbent from dendrimer poly(amidoamine)-grafted cellulose nanofibril aerogels for effective removal of $\mathrm{Cr}(\mathrm{VI})$," Journal of Materials Chemistry A, vol. 3, no. 28, pp. 14703-14711, 2015.

[11] Y.-J. Jiang, X.-Y. Yu, T. Luo, Y. Jia, J.-H. Liu, and X.-J. Huang, “ $\gamma$ $\mathrm{Fe} 2 \mathrm{O} 3$ nanoparticles encapsulated millimeter-sized magnetic chitosan beads for removal of $\mathrm{Cr}(\mathrm{VI})$ from water: Thermodynamics, kinetics, regeneration, and uptake mechanisms," Journal of Chemical and Engineering Data, vol. 58, no. 11, pp. 3142-3149, 2013.

[12] Y. Liu, C. Luo, G. Cui, and S. Yan, "Synthesis of manganese dioxide/iron oxide/graphene oxide magnetic nanocomposites for hexavalent chromium removal," RSC Advances, vol. 5, no. 67, pp. 54156-54164, 2015.

[13] B. Qiu, H. Gu, X. Yan et al., "Cellulose derived magnetic mesoporous carbon nanocomposites with enhanced hexavalent chromium removal," Journal of Materials Chemistry A, vol. 2, no. 41, pp. 17454-17462, 2014. 
[14] H. Liu, S. Liang, J. Gao et al., "Enhancement of Cr(VI) removal by modifying activated carbon developed from Zizania caduciflora with tartaric acid during phosphoric acid activation," Chemical Engineering Journal, vol. 246, pp. 168-174, 2014.

[15] R. V. Kumar, A. K. Basumatary, A. K. Ghoshal, and G. Pugazhenthi, "Performance assessment of an analcime-C zeoliteceramic composite membrane by removal of $\mathrm{Cr}(\mathrm{VI})$ from aqueous solution," RSC Advances, vol. 5, no. 9, pp. 6246-6254, 2015.

[16] W. X. Wang, Y. Qiao, T. Li et al., "Improved removal of Cr(VI) from aqueous solution using zeolite synthesized from coal fly ash via mechano-chemical treatment," Asia-Pacific Journal of Chemical Engineering, vol. 12, no. 2, pp. 259-267, 2017.

[17] L. Deng, Z. Shi, B. Li, L. F. Yang, L. Luo, and X. Z. Yang, "Adsorption of $\mathrm{Cr}(\mathrm{VI})$ and phosphate on $\mathrm{Mg}$-Al hydrotalcite supported kaolin clay prepared by ultrasound-assisted coprecipitation method using batch and fixed-bed systems," Industrial \& Engineering Chemistry Research, vol. 53, no. 18, pp. 77467757, 2014.

[18] W.-B. Zhang, M. Deng, C.-X. Sun, and S.-B. Wang, "Ultrasound-enhanced adsorption of chromium(VI) on Fe3O 4 magnetic particles," Industrial and Engineering Chemistry Research, vol. 53, no. 1, pp. 333-339, 2014.

[19] B. Sarkar, Y. Xi, M. Megharaj, G. S. R. Krishnamurti, D. Rajarathnam, and R. Naidu, "Remediation of hexavalent chromium through adsorption by bentonite based Arquad ${ }^{\circledR}$ 2HT-75 organoclays," Journal of Hazardous Materials, vol. 183, no. 1-3, pp. 87-97, 2010.

[20] N. Ezzatahmadi, G. A. Ayoko, G. J. Millar et al., "Claysupported nanoscale zero-valent iron composite materials for the remediation of contaminated aqueous solutions: A review," Chemical Engineering Journal, vol. 312, pp. 336-350, 2017.

[21] N. Kržišnik, A. Mladenovič, A. S. Škapin, L. Škrlep, J. Ščančar, and R. Milačičc, "Nanoscale zero-valent iron for the removal of $\mathrm{Zn} 2+, \mathrm{Zn}$ (II)-EDTA and $\mathrm{Zn}$ (II)-citrate from aqueous solutions," Science of the Total Environment, vol. 476-477, pp. 20-28, 2014.

[22] X. Y. Li, L. H. Ai, and J. Jiang, "Nanoscale zerovalent iron decorated on graphene nanosheets for $\mathrm{Cr}(\mathrm{VI})$ removal from aqueous solution: surface corrosion retard induced the enhanced performance," Chemical Engineering Journal, vol. 288, pp. 789-797, 2016.

[23] M. Liu, Y. Wang, L. Chen, Y. Zhang, and Z. Lin, " $\mathrm{Mg}(\mathrm{OH})_{2}$ supported nanoscale zero valent iron enhancing the removal of $\mathrm{Pb}(\mathrm{II})$ from aqueous solution," ACS Applied Materials and Interfaces, vol. 7, no. 15, pp. 7961-7969, 2015.

[24] L.-N. Shi, X. Zhang, and Z.-L. Chen, "Removal of Chromium (VI) from wastewater using bentonite-supported nanoscale zero-valent iron," Water Research, vol. 45, no. 2, pp. 886-892, 2011.

[25] Y. Li, T. Li, and Z. Jin, "Stabilization of Fe 0 nanoparticles with silica fume for enhanced transport and remediation of hexavalent chromium in water and soil," Journal of Environmental Sciences, vol. 23, no. 7, pp. 1211-1218, 2011.

[26] R. Saad, S. Thiboutot, G. Ampleman, W. Dashan, and J. Hawari, "Degradation of trinitroglycerin (TNG) using zero-valent iron nanoparticles/nanosilica SBA-15 composite (ZVINs/SBA-15)," Chemosphere, vol. 81, no. 7, pp. 853-858, 2010.

[27] L. Tang, J. Tang, G. Zeng et al., "Rapid reductive degradation of aqueous p-nitrophenol using nanoscale zero-valent iron particles immobilized on mesoporous silica with enhanced antioxidation effect," Applied Surface Science, vol. 333, pp. 220228, 2015.

[28] X. Sun, Y. Yan, J. Li, W. Han, and L. Wang, "SBA-15-incorporated nanoscale zero-valent iron particles for chromium(VI) removal from groundwater: Mechanism, effect of $\mathrm{pH}$, humic acid and sustained reactivity," Journal of Hazardous Materials, vol. 266, pp. 26-33, 2014.

[29] R. Zhang, J. Li, C. Liu et al., "Reduction of nitrobenzene using nanoscale zero-valent iron confined in channels of ordered mesoporous silica," Colloids and Surfaces A: Physicochemical and Engineering Aspects, vol. 425, pp. 108-114, 2013.

[30] E. Petala, K. Dimos, A. Douvalis et al., "Nanoscale zero-valent iron supported on mesoporous silica: Characterization and reactivity for $\mathrm{Cr}(\mathrm{VI})$ removal from aqueous solution," Journal of Hazardous Materials, vol. 261, pp. 295-306, 2013.

[31] M. A. Shevtsov, M. A. Parr, V. A. Ryzhov et al., "Zero-valent Fe confined mesoporous silica nanocarriers (Fe(0) @ MCM-41) for targeting experimental orthotopic glioma in rats," Scientific Reports, vol. 6, Article ID 29247, 2016.

[32] Y. Guo, W. Huang, B. Chen et al., "Removal of tetracycline from aqueous solution by MCM-41-zeolite A loaded nano zero valent iron: Synthesis, characteristic, adsorption performance and mechanism," Journal of Hazardous Materials, vol. 339, pp. 22-32, 2017.

[33] Y. Li, Z. Xiu, T. Li, and Z. Jin, "Stabilization of Fe0 nanoparticles with silica for enhanced transport and remediation of hexavalent chromium in groundwater," ACS Symposium Series, vol. 1124, pp. 307-326, 2013.

[34] H. Yao, Q. Ding, H. Zhou, Z. Zhao, G. Liu, and G. Wang, "An adsorption-reduction synergistic effect of mesoporous $\mathrm{Fe} /$ $\mathrm{SiO} 2-\mathrm{NH} 2$ hollow spheres for the removal of $\mathrm{Cr}(\mathrm{vi})$ ions," $R S C$ Advances, vol. 6, no. 32, pp. 27039-27046, 2016.

[35] J. Lee and J. H. Chang, "Highly ordered magnetic mesoporous silicas for effective elimination of carbon monoxide," Journal of Solid State Chemistry, vol. 188, pp. 100-104, 2012.

[36] H. Wang, X. Zhou, M. Yu et al., "Supra-assembly of siliceous vesicles," Journal of the American Chemical Society, vol. 128, no. 50, pp. 15992-15993, 2006.

[37] K. Qian, J. Wan, F. Liu, H. H. Girault, B. Liu, and C. Yu, "A phospho-directed macroporous alumina - Silica nanoreactor with multi-functions," ACS Nano, vol. 3, no. 11, pp. 3656-3662, 2009.

[38] J. Wan, K. Qian, L. Qiao et al., “TiO2-modified macroporous silica foams for advanced enrichment of multi-phosphorylated peptides," Chemistry - A European Journal, vol. 15, no. 11, pp. 2504-2508, 2009.

[39] J. Yang, H. Zhang, M. Yu et al., "High-content, well-dispersed $\gamma$ $\mathrm{Fe} 2 \mathrm{O} 3$ nanoparticles encapsulated in macroporous silica with superior arsenic removal performance," Advanced Functional Materials, vol. 24, no. 10, pp. 1354-1363, 2014.

[40] J. Yang, P. Yuan, H.-Y. Chen, J. Zou, Z. Yuan, and C. Yu, "Rationally designed functional macroporous materials as new adsorbents for efficient phosphorus removal," Journal of Materials Chemistry, vol. 22, no. 19, pp. 9983-9990, 2012.

[41] SEPA, Analysis Methods for Water and Wastewater, Chinese Environmental Science Press, Beijing, china, 2002.

[42] Z. Aksu, "Equilibrium and kinetic modelling of cadmium(II) biosorption by $C$. vulgaris in a batch system: effect of temperature," Separation and Purification Technology, vol. 21, no. 3, pp. 285-294, 2001. 
[43] P. Yuan, X. Zhou, H. Wang et al., "Electron-tomography determination of the packing structure of mecroporous ordered siliceous foams assembled from vesicles," Small, vol. 5, no. 3, pp. 377-382, 2009.

[44] Y. Zou, X. Wang, A. Khan et al., "Environmental Remediation and Application of Nanoscale Zero-Valent Iron and Its Composites for the Removal of Heavy Metal Ions: A Review," Environmental Science and Technology, vol. 50, no. 14, pp. 72907304, 2016.

[45] L. Ling and W. Zhang, "Visualizing arsenate reactions and encapsulation in a single zero-valent iron nanoparticle," Environmental Science \& Technology, vol. 51, no. 4, pp. 2288-2294, 2017.

[46] L. Lu, Z. Ai, J. Li, Z. Zheng, Q. Li, and L. Zhang, "Synthesis and characterization of $\mathrm{Fe}-\mathrm{Fe} 2 \mathrm{O} 3$ core-shell nanowires and nanonecklaces," Crystal Growth and Design, vol. 7, no. 2, pp. 459-464, 2007.

[47] H. Zeng, J. Li, J. P. Liu, Z. L. Wang, and S. Sun, "Exchangecoupled nanocomposite magnets by nanoparticle self-assembly," Nature, vol. 420, no. 6914, pp. 395-398, 2002.

[48] G. Z. Kyzas, E. A. Deliyanni, and K. A. Matis, "Graphene oxide and its application as an adsorbent for wastewater treatment," Journal of Chemical Technology and Biotechnology, vol. 89, no. 2, pp. 196-205, 2014.

[49] P. Yuan, M. Fan, D. Yang et al., "Montmorillonite-supported magnetite nanoparticles for the removal of hexavalent chromium [Cr(VI)] from aqueous solutions," Journal of Hazardous Materials, vol. 166, no. 2-3, pp. 821-829, 2009.

[50] A. Reyhanitabar, L. Alidokht, A. R. Khataee, and S. Oustan, "Application of stabilized $\mathrm{Fe} 0$ nanoparticles for remediation of Cr(VI)-spiked soil," European Journal of Soil Science, vol. 63, no. 5, pp. 724-732, 2012.

[51] B. Geng, Z. Jin, T. Li, and X. Qi, "Kinetics of hexavalent chromium removal from water by chitosan-Fe0 nanoparticles," Chemosphere, vol. 75, no. 6, pp. 825-830, 2009.

[52] R. Fu, X. Zhang, Z. Xu, X. Guo, D. Bi, and W. Zhang, "Fast and highly efficient removal of chromium (VI) using humussupported nanoscale zero-valent iron: Influencing factors, kinetics and mechanism," Separation and Purification Technology, vol. 174, pp. 362-371, 2017.

[53] W. Stumm, B. Sulzberger, and J. Sinniger, "The coordination chemistry of the oxide-electrolyte interface; the dependence of surface reactivity (dissolution, redox reactions) on surface structure," Croatica Chemica Acta, vol. 63, no. 3, pp. 277-312, 1990.

[54] B. M. SASS and D. RAI, "Solubility of amorphous chromium(III)-Iron(III) hydroxide solid solutions," Inorg Chem U. S, vol. 26, no. $14,1987$.

[55] X.-Q. Li, J. Cao, and W.-X. Zhang, "Stoichiometry of Cr(VI) immobilization using nanoscale zero valent iron (nZVI): A study with high-resolution X-ray photoelectron spectroscopy (HR-XPS)," Industrial and Engineering Chemistry Research, vol. 47, no. 7, pp. 2131-2139, 2008. 

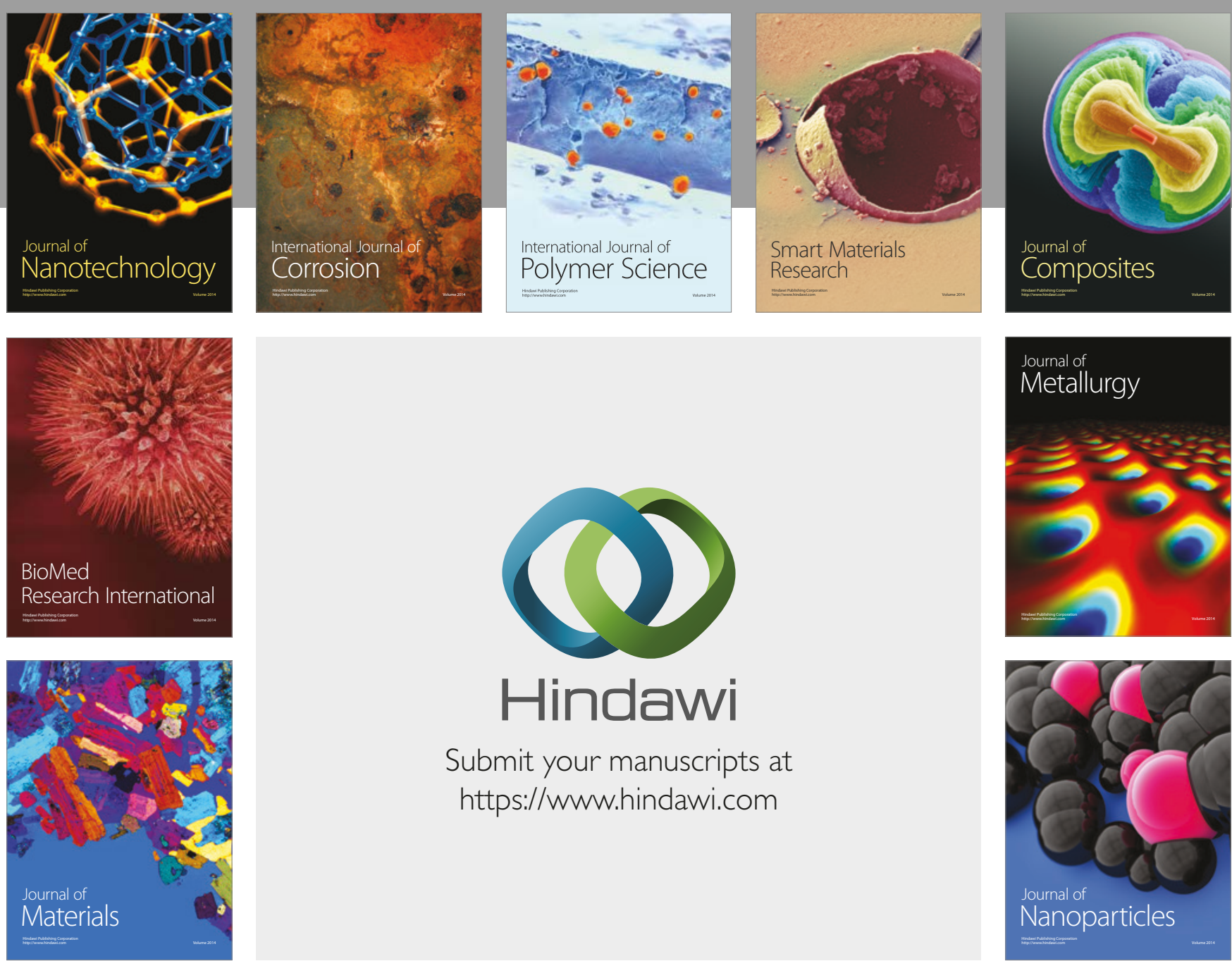

\section{Hindawi}

Submit your manuscripts at

https://www.hindawi.com
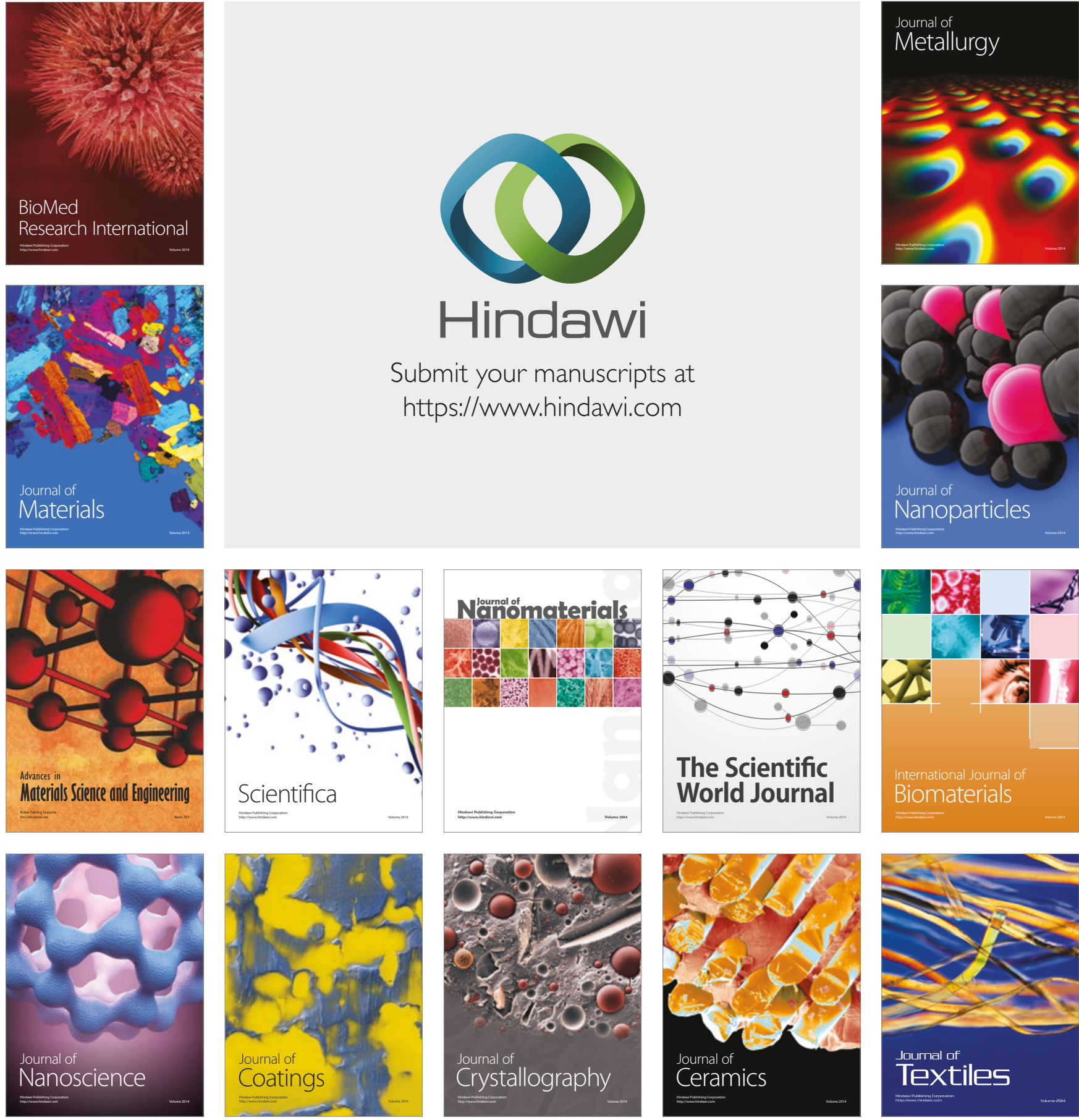

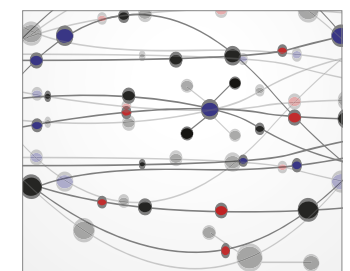

The Scientific World Journal
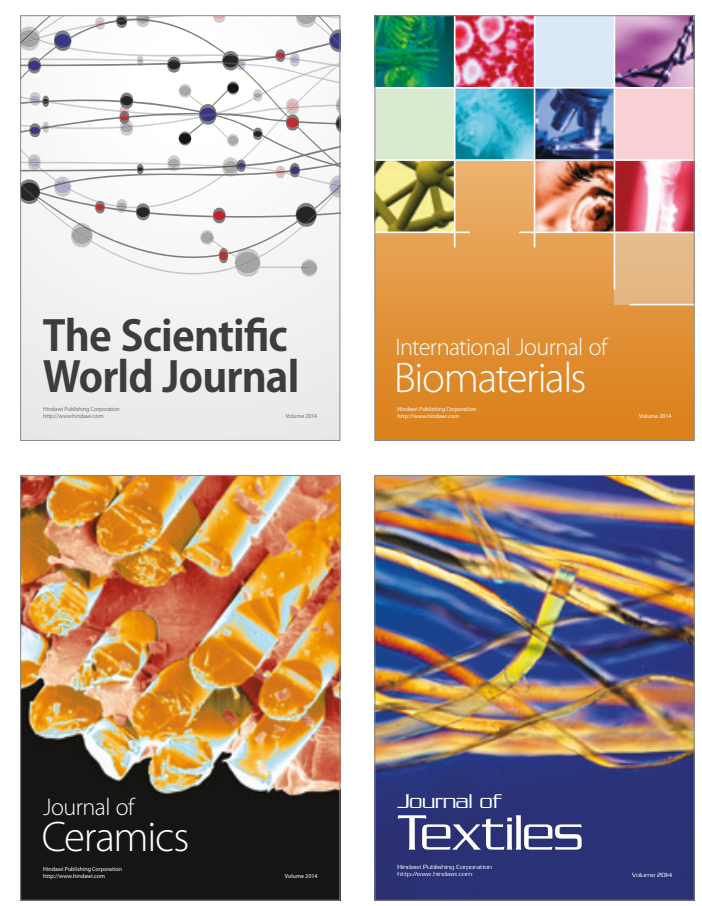